\title{
Adipokines in reproductive function: a link between obesity and polycystic ovary syndrome
}

\author{
Xinwang Chen, Xiao Jia, Jie Qiao', Youfei Guan and Jihong Kang \\ Department of Physiology and Pathophysiology, Peking University Health Science Center, Beijing 100191, China \\ 'Department of Obstetrics and Gynecology, Center for Reproductive Medicine, Peking University Third Hospital, \\ Beijing 100191, China
}

Correspondence

should be addressed to J Kang Email

kangjihong@bjmu.edu.cn

\begin{abstract}
Polycystic ovary syndrome (PCOS) is the most common endocrinopathy associated with infertility and metabolic disorder in women of reproductive age. Dysfunction of adipose tissue has been implicated in the pathophysiology of PCOS. Increasing evidence shows that the dysregulated expression of adipokines, the secreted products of adipose tissue, plays an important role in the pathology of PCOS. Here, we review the role of several identified adipokines that may act as a link between obesity and PCOS. PCOS also reciprocally influences the profile of adipokines. Insight into the underlying mechanisms will help better understand the pathology of PCOS and identify new therapeutic targets of this syndrome.
\end{abstract}

\section{Key Words}

- polycystic ovary syndrome

- adipokines

- obesity

- adipose tissue

Journal of Molecular

Endocrinology

(2013) 50, R21-R37

\section{Introduction}

Polycystic ovary syndrome (PCOS) is one of the most common causes of female infertility, which affects $5-10 \%$ of women of reproductive age. It is a heterogeneous syndrome with the characteristics of hirsutism, acne, anovulation, hyperandrogenemia, polycystic ovaries, and infertility (Goodarzi et al. 2011). In most cases, PCOS also involves metabolic alterations such as insulin resistance (IR), hyperinsulinemia, dyslipidemia, and obesity. Additionally, we have recently revealed altered metabolic profiles in PCOS patients, including the enhanced glycolysis, inhibited tricarboxylic acid cycle, and disturbed levels of amino acids (Sun et al. 2012, Zhao et al. 2012). PCOS can thus lead to an increased risk of developing type 2 diabetes mellitus (T2DM) and cardiovascular disease (CVD) in patients (Diamanti-Kandarakis $\&$ Dunaif 2012).

About $50 \%$ of PCOS patients are obese. Although obesity is an increasingly prevalent health problem worldwide, women with PCOS have a greater risk of overweight, obesity, and central obesity (Lim et al. 2012). Obesity is defined by abnormal or excessive lipid storage. It is characterized by the increased number and volume of adipocytes. A person with a BMI of $30 \mathrm{~kg} / \mathrm{m}^{2}$ or higher is considered obese according to the World Health Organization criteria. Obesity presents a risk to health. It has been well acknowledged that obesity is associated with various diseases, particularly CVDs, metabolic syndrome, and T2DM. The effects of obesity on female reproduction have also been extensively investigated. Obese women seem to have impaired reproductive potential. The adverse effects of obesity on female fertility include impaired ovulation, irregular menstrual cycle, elevated miscarriage rate, lower implantation, pregnancy rates, etc. (Brewer \& Balen 2010). In addition, the distribution of body fat is also important as central/abdominal obesity is associated with IR and has a greater impact on fertility. Women with PCOS are more likely to have central distribution of body fat, which is associated with IR and hyperandrogenemia.

Published by Bioscientifica Ltd 
The presence of obesity can also magnify IR. Obesity is thus one of the crucial parameters and an independent risk factor of PCOS, which plays an important role in the development and manifestations of the clinical, biochemical, and metabolic features of PCOS (Wojciechowski et al. 2012).

In obesity, fat mass massively expands in order to store excessive amount of energy. It is currently realized that adipose tissue is not only the main energy reservoir but also a pivotal endocrine organ. Adipose tissue has been revealed to play important roles in the regulation of many physiological processes, such as reproduction, immune response, and glucose and lipid metabolism, by secreting a variety of bioactive cytokines named adipokines. Adipokines comprise both adipose-specific cytokines or cytokines predominantly secreted by adipocytes, such as leptin, resistin, adiponectin (APN), visfatin, and omentin, and nonadipose-specific cytokines such as retinol binding protein-4 (RBP4), lipocalin-2 (LCN2), chemerin, interleukin 6 (IL6), IL1 $\beta$, and tumor necrosis factor $\alpha$ (TNF $\alpha)$. Abnormal levels of adipokines have been shown to be strongly associated with IR and T2DM. In patients with PCOS, dysfunction of adipose tissue has been observed with the over-production of pro-inflammatory adipokines such as TNF $\alpha$, and the reduced expression of some 'beneficial adipokines' such as APN. Substantial evidence indicates that obesity plays a pivotal role in the pathogenesis of PCOS. In this review, we discuss the roles of several identified adipose-specific and some of nonadipose-specific adipokines in female reproduction that may act as links between obesity and PCOS. Other adipokines, such as TNF $\alpha$, IL6, and IL1 $\beta$, are best known for their association with inflammation and have been reviewed in detail elsewhere (Bohler et al. 2010).

\section{Leptin}

Named from the Greek leptos (meaning thin), leptin is a 167 -amino acid protein encoded by the $o b$ gene. It is an important hormone involved in the regulation of food intake, energy balance, and body weight (Morris \& Rui 2009). Leptin is the first discovered adipokine that has led people to realize the functions of adipose tissue as not only a well-recognized energy reservoir but also a key endocrine organ in the body. Leptin is predominantly secreted by adipose tissue. Its expression is also found in the stomach, placenta, hypothalamus, pituitary, and mammary gland (Zhang et al. 1994, Masuzaki et al. 1997, Smith-Kirwin et al. 1998, Mix et al. 1999, Sahu 2004). The leptin receptor (LEPR), also called the obesity receptor (Ob-R), is a single transmembrane domain receptor that is highly expressed in the choroid plexus (Tartaglia et al. 1995). There are six isoforms of the LEPR (Ob-Ra, b, c, d, e, and f) due to alternative RNA splicing (Gorska et al. 2010). Among them, a soluble isoform Ob-Re is able to regulate serum leptin concentration, whereas only the full-length isoform Ob-Rb can fully transduce activation signal into the cell.

Leptin is constitutively secreted by adipocytes in proportion to the adipose mass (Budak et al. 2006). It suppresses food intake and promotes energy expenditure mainly via its direct effects on hypothalamic neurons (Morris \& Rui 2009), and it is thus considered an antiobese hormone. Mutations of the leptin gene ( $o b$ gene), which produce only defective and nonfunctional leptin, result in genetically obese mice $(o b / o b$ mice) due to hyperphagia and increased lipogenesis (Zhang et al. 1994). Similar phenotypes were observed with the characteristics of obesity and diabetes in $d b / d b$ mice that have mutations of the LEPR gene ( $d b$ gene; Chen et al. 1996, Lee et al. 1996). Leptin levels decrease with fasting and increase in food intake (Ahima et al. 1996, Budak et al. 2006). At high physiological concentrations, leptin causes a decrease in food intake, an increase in energy expenditure, and a shift to increased fatty acid oxidation. High serum leptin levels are detected in obese patients, who are described as leptin resistant (Myers et al. 2010). Several mechanisms have been proposed to be involved in leptin resistance, including impaired leptin trafficking and signaling, endoplasmic reticulum stress, defects in leptin-targeted neural circuits, etc. (Morris \& Rui 2009).

In addition to its critical roles in regulating energy homeostasis, leptin is also important in female reproduction. The deficiency of leptin or LEPR due to lossof-function mutations in the corresponding genes has been linked to infertility and delayed puberty development in humans and rodents. Moreover, leptin and its receptor have been implicated in maintaining other normal female reproductive functions, including lactation, folliculogenesis, ovarian steroidogenesis, the maintenance of mammary gland morphology and function, the development of dominant follicles and oocytes, maturation endometrial development, menstrual cycle regulation (Agarwal et al. 1999, Zachow et al. 1999), and endometrial receptivity (Marin Bivens \& Olster 1997, Bluher \& Mantzoros 2007, Israel \& Chua 2010, Clempson et al. 2011, Dos Santos et al. 2012). Leptin signaling also contributes to the hypothalamic-pituitary-gonadal (HPG) axis. In cultured pituitary cells from female rats, leptin could induce the production and secretion of both LH and

Published by Bioscientifica Ltd. 
FSH, with or without GNRH (Ogura et al. 2001). In addition, mice lacking leptin or the LEPR exhibit low LH levels and incomplete development of reproductive organs. Administration of leptin to $o b / o b$ mice induces pubertal development and maturation of reproductive organs, increases LH secretion, and restores fertility, demonstrating the importance of leptin signaling in female reproduction (Donato et al. 2011). Abnormal leptin levels have been reported in the peritoneal fluid in women with endometriosis (De Placido et al. 2001, Wu et al. 2002, Bedaiwy 2005). Additionally, in women with hypothalamic amenorrhea due to energy deficiency, leptin treatment resulted in the recovery of menstruation and corrected the abnormalities in gonadal, GH, and adrenal axes, further indicating the requirement of leptin in normal reproductive and neuroendocrine functions (Welt et al. 2004, Chou et al. 2011).

The first study on leptin and its signaling in PCOS was reported in 1996 (Brzechffa et al. 1996), 2 years after the discovery of leptin (Zhang et al. 1994). Data from that study suggested the possible involvement of abnormal leptin signaling in the reproductive system in certain cases of PCOS. Later, a series of studies explored the role of leptin as a potential player in PCOS. It is now widely acknowledged that serum leptin levels are positively correlated with BMI and percent body fat. In addition, leptin level is associated with estrogen or androgen levels and the ratios of E1/sex hormone-binding globulin (SHBG) and E2/SHBG. But no correlation between leptin and androstenedione or testosterone was observed in either control or PCOS groups. It still remains controversial whether serum leptin levels are different in PCOS compared with control subjects, as shown in Table 1 . Increased serum leptin concentrations have been observed in women with PCOS in comparison to weight-matched controls in certain studies (Brzechffa et al. 1996, Vicennati et al. 1998, El Orabi et al. 1999, Brannian \& Hansen 2002, Pehlivanov \& Mitkov 2009, Yildizhan et al. 2011). Wang et al. (2012a) also reported significantly higher mRNA expression of leptin in subcutaneous adipose tissue of PCOS patients compared with controls. Most studies, however, did not find any significant differences in serum leptin levels in women with PCOS when compared with age- and weight-matched controls (Table 1; Chapman et al. 1997, Laughlin et al. 1997, Mantzoros et al. 1997, Micic et al. 1997, Rouru et al. 1997, Gennarelli et al. 1998, Carmina et al. 2009). No significant difference was found in circulating leptin levels between the ovulatory and anovulatory PCOS patients either (Carmina et al. 2009). Furthermore, a very recent study showed that there was no effect of PCOS on either adipose leptin expression or plasma leptin levels (Svendsen et al. 2012). These conflicting results might be explained by the different ethnicity and heterogeneity of the PCOS group, or the different sampling method to get fat biopsies in the studies. In addition, a single nucleotide polymorphism, G19A, detected in leptin gene was not found to be associated with PCOS (Pusalkar et al. 2010). Treatment with low-dose oral contraceptives (Sagsoz et al. 2009) or administration of conjugated estrogens and anti-androgens (Panidis et al. 2000) did not seem to affect serum leptin levels in women with PCOS.

Obesity and IR are crucial parameters of PCOS. As leptin is primarily secreted by adipose tissue, it is interesting to know whether serum leptin levels are correlated with IR in PCOS. No significant differences were observed in serum leptin or LEPR levels between PCOS IR and PCOS non-IR groups (Wang et al. 2011). However, Yildizhan et al. (2011) observed an association between serum leptin levels with IR in young women with PCOS. Troglitazone is a drug that improved IR and hyperinsulinemia. Treatment with troglitazone did not seem to alter leptin levels (Mantzoros et al. 1997). By contrast, administration of metformin, an insulin sensitizer widely used for the treatment of T2DM, considerably reduced serum leptin concentrations in obese (MorinPapunen et al. 1998) and non-obese PCOS patients (Marciniak et al. 2009). The correlation between leptin and IR is thus still a matter of debate. Further research is required to clarify the relationship between leptin and IR in PCOS.

Genetic variants of the HPG axis are associated with a modest but significant effect on the phenotype of PCOS (Valkenburg et al. 2009). As described earlier, leptin may affect reproduction by modulating HPG axis function at both central and ovarian levels. Questions are then raised as to whether leptin contributes to the phenotype of PCOS by regulating the HPG axis. Sir-Petermann et al. (1999) found that circulating leptin and LH pulses are synchronized in both normal women and patients with PCOS. Thus, the leptin pulse does not seem to be specific to PCOS and the real significance of the apparent copulsatility between LH and leptin needs to be elucidated.

\section{Adiponectin}

APN, also referred to as ACRP30 or AdipoQ, is the most abundant secreted protein expressed exclusively in adipose tissue (Campos et al. 2007, Bohler et al. 2010). There are three major forms of APN: a trimeric low-molecular-weight (LMW) form, a hexameric

Published by Bioscientifica Ltd 
Table 1 Serum levels of adipokines in PCOS patients compared with controls

\begin{tabular}{|c|c|c|}
\hline Adipokines & $\begin{array}{l}\text { Serum levels in PCOS } \\
\text { compared with controls }\end{array}$ & References \\
\hline \multirow[t]{2}{*}{ Leptin } & Increased & $\begin{array}{l}\text { Brzechffa et al. (1996), Vicennati et al. (1998), El Orabi et al. (1999), Brannian \& Hansen } \\
\text { (2002), Pehlivanov \& Mitkov (2009), and Yildizhan et al. (2011) }\end{array}$ \\
\hline & Similar & $\begin{array}{l}\text { Chapman et al. (1997), Laughlin et al. (1997), Mantzoros et al. (1997), Micic et al. } \\
\text { (1997), Rouru et al. (1997), Gennarelli et al. (1998), Carmina et al. (2009), and Svendsen } \\
\text { et al. (2012) }\end{array}$ \\
\hline \multirow[t]{2}{*}{ APN } & Decreased & $\begin{array}{l}\text { Ardawi \& Rouzi (2005), Escobar-Morreale et al. (2006), Pinhas-Hamiel et al. (2009), } \\
\text { Manneras-Holm et al. (2011), and Shin et al. (2011) }\end{array}$ \\
\hline & Similar & Orio (2003), Spranger et al. (2004), and Lecke et al. (2011) \\
\hline \multirow[t]{2}{*}{ Resistin } & Increased & Munir et al. (2005) \\
\hline & Similar & $\begin{array}{l}\text { Panidis et al. (2004), Seow (2004), Escobar-Morreale et al. (2006), Seow et al. (2007), } \\
\text { Olszanecka-Glinianowicz et al. (2011), and Zhang et al. (2011) }\end{array}$ \\
\hline \multirow[t]{2}{*}{ Visfatin } & Increased & $\begin{array}{l}\text { Tan et al. (2006a, b), Chan et al. (2007), Kowalska et al. (2007), Panidis et al. (2008), } \\
\text { Carmina et al. (2009), Ozkaya et al. (2010), Plati et al. (2010), and Seow et al. (2011) }\end{array}$ \\
\hline & Similar & Guducu et al. (2012), Lajunen et al. (2012), and Olszanecka-Glinianowicz et al. (2012) \\
\hline Omentin-1 & Decreased & Tan et al. $(2008 a, b)$ and Choi et al. (2011) \\
\hline RBP4 & Increased & Carmina et al. (2009) and Mahde et al. (2009) \\
\hline \multirow[t]{2}{*}{ Lipocalin-2 } & Increased & Cakal et al. (2011) \\
\hline & Similar & Panidis et al. (2010) and Koiou et al. (2012) \\
\hline Chemerin & Increased & Tan et al. (2009) \\
\hline
\end{tabular}

medium-molecular-weight (MMW) form, and a multimeric high-molecular-weight (HMW) form (Kadowaki \& Yamauchi 2005, Michalakis \& Segars 2010). Biological effects of APN vary from each different structure, with HMW most actively suppressing hepatic glucose production and LMW most potent for induction of AMP-activated protein kinase (AMPK) activation and fatty acid $\beta$-oxidation in skeletal muscle (Michalakis \& Segars 2010). Three putative receptors have been identified for APN, namely AdipoR1, AdipoR2, and T-cadherin (T-cad; Hug et al. 2004, Kadowaki et al. 2006). AdipoR1 and AdipoR2 receptors are ubiquitously expressed and have been demonstrated to be expressed in female reproductive tissues, including ovary, placenta, endometrium, and oviduct (Michalakis \& Segars 2010). A body of literature supports the role of AdipoR1 and AdipoR2 in reproduction. By contrast, T-cad (Cdh13) has been shown to be critical for APN-mediated beneficial effects in the heart (Denzel et al. 2010). T-cad is a glycolipid-anchored extracellular protein. It has been identified as a receptor for MMW and HMW forms of APN. Although T-cad has been found to be expressed in rat ovaries (Machell et al. 2000), the role of T-cad in female reproduction still remains unknown.

Circulating APN levels decrease with obesity and increase with weight loss (Gavrila et al. 2003, EscobarMorreale 2006, Pietilainen et al. 2006). The major action of APN is to increase insulin sensitivity by stimulating glucose uptake in the liver and muscle, decreasing hepatic gluconeogenesis, and promoting fatty acid $\beta$-oxidation in the skeletal muscle. Consequently, APN reduces triglyceride (TG) accumulation and enhances insulin sensitivity (Bohler et al. 2010, Michalakis \& Segars 2010). The intracellular signal transduction pathway of APN has been shown to involve the activation of AMPK by APN stimulation (Kadowaki et al. 2006, Bohler et al. 2010). Several other signaling pathways have also been suggested, including PI3K/Akt and MAPK pathways (Ouchi et al. 2004, Luo et al. 2005).

APN is described as a 'beneficial' adipokine in reproduction (Campos et al. 2007). Both ADIPOR1 and ADIPOR2 are expressed in human hypothalamus and pituitary (Rodriguez-Pacheco et al. 2006, Kubota et al. 2007). It has been shown that APN inhibits LH and GNRH release (Lu et al. 2008, Wen et al. 2008), indicating its possible role in modulating the central reproductive endocrine axis (Psilopanagioti et al. 2009). At physiological levels, APN induces the expression of genes associated with periovulatory remodeling of the ovarian follicle in porcine granulose cells (Ledoux et al. 2006). Serum APN levels were observed to increase in women following treatment with human chorionic gonadotropin during the IVF process (Liu et al. 2006). Collectively, these results suggest that APN may play an active role in ovulation. Moreover, APN reduced insulin-induced progesterone and androstenedione production as well as insulin-like growth factor 1-induced $L H R, C Y P 11 A 1$, and CYP17A1 gene expression in bovine theca cells in vitro, indicating the possible involvement of APN in the pathophysiology of

Published by Bioscientifica Ltd. 
PCOS via its regulatory effects on steroidogenesis (Lagaly et al. 2008). Indeed, circulating APN levels are lower in obese subjects and are negatively correlated with testosterone levels (Orio 2003, Xu et al. 2005, Escobar-Morreale 2006). Testosterone has an inhibitory effect on the secretion of HMW APN (Xu et al. 2005). In the uterus, the presence of APN, AdipoR1, and AdipoR2 has been demonstrated in the mouse decidual cells of the implantation site and in artificially decidualized cells (Kim et al. 2011). Reduced expression of $A D I P O R 1$ and $A D I P O R 2$ was also observed in endometria of women with recurrent implantation failure compared with fertile women (Dos Santos et al. 2012), suggesting an important role of APN signaling in uterine receptivity and its possible contribution to implantation failures and pregnancy loss in women with maternal metabolic conditions such as obesity and PCOS. Results with respect to serum APN levels in PCOS compared with healthy controls are still controversial (Orio 2003, Spranger et al. 2004, Ardawi \& Rouzi 2005, Pinhas-Hamiel et al. 2009, Lecke et al. 2011, Manneras-Holm et al. 2011, Shin et al. 2011; Table 1). Serum APN concentrations were observed to be reduced in PCOS patients compared with controls in some studies (Ardawi \& Rouzi 2005, Escobar-Morreale et al. 2006, Pinhas-Hamiel et al. 2009, Manneras-Holm et al. 2011, Shin et al. 2011), whereas in other reports, serum APN concentrations did not seem to differ between PCOS and controls (Orio 2003, Spranger et al. 2004, Lecke et al. 2011). A meta-analysis revealed that serum APN levels are lower in women with PCOS compared with BMI-matched healthy controls (Toulis et al. 2009). In addition, it was found that obese PCOS patients have lower APN levels than non-obese PCOS patients. HMW APN has been demonstrated to be most closely associated with insulin sensitivity (Pajvani et al. 2004). It was reported that reduced serum levels of HMW APN are selectively reduced in women with PCOS, independent of BMI and IR (O'Connor et al. 2010). Several other reports also support the association of APN levels with IR (Trolle et al. 2010, Lecke et al. 2011). Metformin has been increasingly used in the treatment of PCOS, which effectively reduces IR in obese PCOS patients. Treatment of metformin for 6 months, however, did not affect APN levels (Trolle et al. 2010). Upregulated expression of ADIPOR1 and ADIPOR2 at both mRNA and protein levels has been observed in the subcutaneous and omental adipose tissues in insulin-resistant women with PCOS compared with controls (Tan et al. 2006b). Moreover, a number of studies investigated the association of PCOS with polymorphisms of the APN gene. Gao et al. (2012) recently found a significant association of APN T45G polymorphism with PCOS by a meta-analysis. As the most abundant adipokine in the human body, APN seems to play an important role in the pathogenesis of PCOS.

\section{Resistin}

Resistin is a small cysteine-rich protein secreted as a 94-amino acid polypeptide. It was first found by Steppan et al. (2001) during their study of the effects of PPAR $\gamma$ agonists on glucose homeostasis. Steppan et al. named this protein 'resistin' for its property of 'resistance to insulin' in mice and this gene was later designated as Retn. In the same year, this adipokine was also discovered by another group (Kim et al. 2001) and its inhibitory effect on adipocyte differentiation and its association with IR have made it a potential link between obesity and diabetes.

In mice, resistin is primarily secreted by mature white adipocytes. Resistin has been demonstrated to be involved in IR and T2DM in rodents as circulating resistin levels are increased in diet-induced and genetic forms of obesity and are decreased by the anti-diabetic drug rosiglitazone. Human resistin, however, is mainly secreted by peripheral blood mononuclear cells (Tilg \& Moschen 2006). It competes with lipopolysaccharide for the binding to Toll-like receptor 4 and is thus involved in the inflammatory process. The expression of human resistin is predominantly localized in macrophages and stromal cells in adipose tissue rather than adipocytes (Bohler et al. 2010, Schwartz \& Lazar 2011). A high level of resistin gene expression was observed in human preadipocytes, which decreased during adipocyte differentiation. It should be noted that the relationship between resistin and IR in humans is complicated. It is still a subject of debate as some studies revealed a positive correlation between resistin and IR (Silha et al. 2003, Azuma et al. 2004, Kunnari et al. 2005, Gerrits et al. 2012), whereas others failed to detect changes in resistin levels in obesity, IR, or T2DM (Kielstein et al. 2003, Lee et al. 2003, Pfutzner et al. 2003, Heilbronn et al. 2004, Chen et al. 2005, Akdeniz et al. 2011).

As a secreted circulating protein, resistin can exert its functions in both endocrine and paracrine manners (Schwartz \& Lazar 2011). In rodent liver and muscle, resistin has been shown to inhibit AMPK and thus decrease hepatic gluconeogenesis and stimulate muscle glucose uptake (Banerjee et al. 2004, Muse et al. 2004). In mouse adipose tissue, resistin activates suppressor of cytokine signaling-3 (SOCS-3), an anti-inflammatory mediator (Steppan et al. 2005), which is known to suppress insulin

Published by Bioscientifica Ltd. 
signaling in several tissues (Senn et al. 2003). In primary human aortic endothelial cells, resistin activates p38 MAPK and thus upregulates phosphatase and tensin homolog deleted on chromosome 10 (PTEN) expression (Shen et al. 2006), suggesting an inhibitory effect of resistin on insulin signaling. In a very recent study, Sanchez-Solana et al. (2012) identified mouse resistin as a ligand for the tyrosine kinase-like orphan receptor (ROR1) to regulate SOCS-3, glucose transporter 4 (GLUT4), and GLUT1 expression and to modulate glucose uptake and promote adipogenesis of 3T3-L1 cells, which thus opens a new line of research to explain the underlying mechanisms of resistin action in adipogenesis and the development of IR. In addition to its expression in adipose tissue and macrophages, resistin mRNA was also found in hypothalamo-pituitary axis, rat testis, and rat and bovine ovaries (Maillard et al. 2011), and resistin has been suggested to affect bovine and rat granulose cell steroidogenesis and proliferation (Maillard et al. 2011, Spicer et al. 2011).

Data regarding the levels of resistin in PCOS patients are still controversial (Table 1). Seow (2004) did not find any significant difference in either serum or follicular fluid resistin levels between PCOS and control groups, which is supported by several other studies (Panidis et al. 2004, Escobar-Morreale et al. 2006, Seow et al. 2007, OlszaneckaGlinianowicz et al. 2011, Zhang et al. 2011), even though serum APN levels were significantly lower in obese than in normal-weight women (Escobar-Morreale et al. 2006). Escobar-Morreale et al. (2006) showed that serum resistin levels were increased in overweight and obese women compared with lean subjects, irrespective of their PCOS or controls status. Although resistin mRNA levels were twofold higher in adipocytes from PCOS than in those from normal controls (Seow 2004), adipocyte-produced resistin does not seem to play a key role in the body as adipocytes are not the major source of circulating resistin in humans. Adipocyte resistin mRNA expression was reported to be significantly decreased after laparoscopic ovarian electrocautery in both obese and lean women with PCOS (Seow et al. 2007). Moreover, no significant difference in plasma resistin levels was observed between PCOS-IR and PCOS-non-IR groups (Zhang et al. 2011). On the other hand, Munir et al. (2005) found a $40 \%$ increase in mean serum resistin concentration in PCOS patients and a positive correlation with BMI and testosterone. In addition, resistin was observed to synergize with insulin to augment ovarian androgen production by enhancing $17 \alpha$-hydroxylase mRNA expression and activity in ovarian theca cells.
In a study on resistin promoter, no strong evidence was found for association of variation in resistin gene promoter with the phenotypes of PCOS (Urbanek et al. 2003). Instead, the resistin gene polymorphism is associated with BMI in women with PCOS, suggesting that resistin might be related to adiposity in PCOS (Xita et al. 2004). In addition, in a randomized placebo-controlled study, treatment with the insulin sensitizer rosiglitazone significantly reduced serum resistin levels in overweight women with PCOS, implying the contribution of resistin to insulin sensitivity improvement during treatment (Majuri et al. 2007). In summary, resistin seems to be an important adipokine that is involved in obesity, IR, and PCOS.

\section{Visfatin}

Visfatin, previously known as pre-B cell colony enhancing factor (PBEF; Samal et al. 1994), is a highly conserved, $52 \mathrm{kDa}$ protein expressed in a variety of tissues and cell types, including adipocytes, lymphocytes, bone marrow, liver, muscle, trophoblast, and fetal membranes (Fukuhara et al. 2005). Visfatin was initially discovered by Fukuhara et al. (2005) who found that the mRNA level of a secreted protein was much more abundant in visceral fat than in subcutaneous fat and was thus named visfatin. Data from in vitro experiments showed that visfatin stimulates glucose uptake in adipocytes and muscle cells and suppresses glucose release from hepatocytes (Fukuhara et al. 2005, Hug \& Lodish 2005). It was reported that visfatin binds to insulin receptor at a different site from that of insulin and exhibits insulin-mimetic actions. Administration of recombinant visfatin lowered plasma glucose levels in mice. In addition, heterozygous knockout mice (visfatin ${ }^{+-}$) in which one copy of the visfatin gene has been deleted have higher plasma glucose levels under both fasting and feeding conditions compared with wildtype mice. The relationship between visfatin and insulin action, however, is currently unclear due to the retraction of part of the work originally published in Science (Fukuhara et al. 2007).

Although there are conflicting data on the relationship between visfatin and obesity (Haider et al. 2006, Pagano 2006, Choi et al. 2007, Filippatos et al. 2007, Panidis et al. 2008, Chang et al. 2010), a recent metaanalysis revealed that plasma visfatin is significantly increased in subjects diagnosed with overweight/obesity, T2DM, metabolic syndrome, and CVD (Chang et al. 2011). Circulating visfatin levels were also found to be positively associated with IR (Chang et al. 2011). The changes

Published by Bioscientifica Ltd 
observed in visfatin levels after exercise or gastric banding surgery are also controversial. On the one hand, it was shown in some reports that visfatin mRNA level in adipose tissue was increased in response to exercise and the circulating visfatin concentration was upregulated after weight loss induced by gastroplastic surgery (Krzyzanowska et al. 2006, Frydelund-Larsen et al. 2007). Serum visfatin concentration was also reported to increase after bariatric surgery related to the amount of weight lost in morbidly obese women (Botella-Carretero et al. 2008). On the other hand, in some other studies, plasma visfatin levels in obese subjects were reported to reduce with weight loss, either by exercise or gastric banding surgery (Haider et al. 2006, Choi et al. 2007). This discrepancy is difficult to explain. It may result from the different BMI value after weight loss, the type of surgical procedure, or other complex factors such as genetic variation and individual glucose tolerance state.

It has previously been reported that the gene expression and circulating levels of visfatin were increased in women with PCOS compared with age- and BMImatched controls (Tan et al. 2006a, Chan et al. 2007, Kowalska et al. 2007, Panidis et al. 2008, Carmina et al. 2009, Ozkaya et al. 2010, Plati et al. 2010, Seow et al. 2011), as shown in Table 1 . However, several recently published studies did not find a difference in plasma or serum visfatin levels between patients with PCOS and control groups (Guducu et al. 2012, Lajunen et al. 2012, Olszanecka-Glinianowicz et al. 2012). Moreover, Chan et al. (2007) did not observe any correlation between visfatin concentrations and testosterone, insulin, and LH levels in either PCOS or control groups. A positive correlation, however, was found between plasma visfatin concentration, fasting insulin, and homeostasis model assessment (HOMA)-IR, as reported by Tan et al. (2006a). It is interesting to find that visfatin levels in PCOS women were significantly reduced after a 3-month treatment with metformin and visfatin could differentiate between women with or without increased diabetogenic risk at a cutoff value of $19.24 \mathrm{ng} / \mathrm{ml}$ (Ozkaya et al. 2010). In addition, such a treatment resulted in a significant decrease in BMI, HOMA-IR, fasting insulin, and free testosterone, suggesting the possible involvement of visfatin in the pathophysiology of PCOS and its related complications. Many studies also demonstrated that visfatin displayed pro-inflammatory properties and modulated immune functions (Moschen et al. 2007, Adya et al. 2008, Romacho et al. 2009, Fan et al. 2011, Jacques et al. 2012). Visfatin was reported to induce NF-кB signaling in human endothelial cells and activated MMP-
$2 / 9$, indicating its possible role in the pathogenesis of PCOS with its pro-inflammatory characteristics (Adya et al. 2008).

\section{Omentin-1}

Omentin-1, also named omentin, is a novel visceral fat depot-specific secretory protein identified by Yang et al. (2006) from a human omental fat cDNA library. It is predominantly produced by visceral adipose tissue in humans and rhesus monkeys (Yang et al. 2006). The expression of omentin-1 has also been detected in other tissues at low levels and omentin-1 is thus named intelectin (Tsuji et al. 2001), intestinal lactoferrin receptor (Suzuki et al. 2001), or endothelial lectin (Lee et al. 2001). A homolog of omentin, referred to as omentin-2, shares $83 \%$ amino acid identity with omentin/intelectin (omentin-1; Lee et al. 2001). Omentin-1 and omentin-2 genes are localized adjacently in the 1q22-q23 chromosomal region that has been linked to T2DM in various populations (Hanson et al. 1998, Elbein et al. 1999, Vionnet et al. 2000, Wiltshire et al. 2001).

It has been reported that omentin-1 is the major circulating form of omentins in human plasma. Plasma omentin-1 concentrations were negatively correlated with BMI, waist circumference, and IR as measured by HOMA and positively correlated with APN and HDL levels (de Souza Batista et al. 2007). Circulating omentin-1 levels were found to increase after weight loss-induced improvement of insulin sensitivity (Moreno-Navarrete et al. 2010). In addition, omentin-1 levels decrease in pre-diabetic stage, T1DM, and newly diagnosed, untreated T2DM patients (Tan et al. 2008b, Pan et al. 2010). It has been shown that omentin-1 enhances insulin sensitivity by activating Akt and increases insulin-stimulated glucose uptake both by subcutaneous and omental adipocytes in vitro (Yang et al. 2006). But unlike visfatin, omentin-1 does not stimulate basal glucose transport on its own, suggesting the lack of intrinsic insulin-mimetic activity of omentin-1.

In the setting of PCOS, plasma omentin-1 concentrations were found to decrease in non-obese women with normal glucose tolerance and PCOS and overweight insulin-resistant women with PCOS when compared with control subjects (Table 1; Tan et al. 2008a, Choi et al. 2011). In addition, the expression of omentin-1 at both mRNA and protein levels in omental adipose tissue is decreased in non-obese women with PCOS compared with controls (Tan et al. 2008a). Mahde et al. (2009) demonstrated that 93.33 and $98.30 \%$ of PCOS patients have

Published by Bioscientifica Ltd. 
abnormal ratios of omentin- 1 to insulin and omentin- 1 to resistin respectively. Treatment with metformin for 3 or 6 months significantly increased serum omentin-1 levels as well as the ratio of omentin- 1 to insulin in PCOS patients (Shaker et al. 2010, Tan et al. 2010a). It should be noted that omentin-1 has been shown to display antiinflammatory properties as well (Tan et al. 2010b, Yamawaki et al. 2011, Kazama et al. 2012). For instance, omentin-1 can attenuate TNF $\alpha$-induced inflammation both in endothelial cells and in vascular smooth muscle cells (Yamawaki et al. 2011, Kazama et al. 2012). These data suggest that dysregulated omentin-1 levels may contribute to the pathophysiology of PCOS.

\section{Retinol binding protein-4}

RBP4 is a protein synthesized mainly by hepatocytes, followed by adipocytes. It has been regarded as a novel adipokine since a study on adipose-specific Glut 4 knockout mice in 2005 (Yang et al. 2005). Although it is a transport protein for vitamin A (retinol), RBP4 has been recognized as an adipokine that affects systemic insulin sensitivity and glucose homeostasis (Graham et al. 2006). Serum RBP4 levels are upregulated in insulin-resistant states in humans and in mice. On the other hand, serum RBP4 can also provoke IR. In mice, peritoneal injection of recombinant human RBP4 induces systemic IR. Conversely, genetic deletion of RBP4 enhances insulin sensitivity. A negative correlation was found between plasma RBP4 levels and peripheral insulin sensitivity. In addition, RBP4 has been related to obesity. Circulating RBP4 levels and RBP4 mRNA expression in visceral and subcutaneous abdominal adipose tissue are increased in obese patients compared with lean subjects. Reduction in body weight after dietary interventions, especially with a carbohydrate-restricted diet, results in decreased serum RBP4 levels (Volek et al. 2009). In human subcutaneous and omental adipose tissue explants, $17 \beta$-estradiol significantly increased RBP4 mRNA expression, protein levels, and secretion into the culture media. By contrast, testosterone, insulin, androstenedione, or DHEA-S did not have a marked effect on RBP4 expression (Tan et al. 2007).

Up until now, there have been only a few studies investigating the involvement of RBP4 in the pathophysiology of PCOS. A significant increase in serum RBP4 levels has been observed in PCOS patients compared with controls (Table 1; Carmina et al. 2009, Mahde et al. 2009). Obese or overweight women with PCOS have increased serum RBP4 levels compared with age- and BMI-matched healthy controls (Tan et al. 2007, Yildizhan et al. 2011).
Additionally, there was a significant increase in $R B P 4$ mRNA in subcutaneous and omental adipose tissue as well as isolated adipocytes of overweight PCOS women compared with controls (Tan et al. 2007). No significant correlation was found between RBP4 and IR in subjects with PCOS. However, there was a positive correlation between RBP4 levels and LH and TG. In addition, no difference in serum RBP4 levels was observed between ovulatory and anovulatory PCOS patients (Carmina et al. 2009). In PCOS patients who underwent controlled ovarian hyperstimulation for an IVF-embryo transfer, serum RBP4 was found to be significantly decreased during the process (Orvieto et al. 2010). But there is no correlation between serum RBP4 levels and IVF treatment variables or outcome. It is also noteworthy that retinoids, which include retinol and its derivatives, have been found to regulate androgen biosynthesis and steroidogenic enzyme expression in normal and PCOS theca cells (Wood et al. 2004). Wickenheisser et al. further demonstrated that retinol stimulated CYP17 mRNA accumulation and promoter function in PCOS but not normal theca cells in humans, which could contribute to the excessive thecaderived androgen production in PCOS patients (Wickenheisser et al. 2005). It would thus be intriguing to measure the hepatic level of RBP4 that transports retinol from the liver to target tissues. Indeed, women with PCOS had a statistical trend for higher RBP4 compared with controls (Sopher et al. 2012). But the relationship between retinol, RBP4, and the increased ovarian androgen synthesis in women with PCOS needs to be evaluated in future studies.

\section{Lipocalin-2}

LCN2, also named neutrophil gelatinase-associated lipocalin (NGAL), is a $25 \mathrm{kDa}$ glucoprotein belonging to the lipocalin superfamily (Triebel et al. 1992, Kjeldsen et al. 1993). It is able to transport small lipophilic ligands, such as lipopolysaccharides (Bratt et al. 1999), through the hydrophilic body fluid and acts as a bacteriostatic protein. LCN2 was first isolated from human neutrophils and has now been found to be expressed in several types of cells, including adipocytes (Zhang et al. 2008), macrophages (Zhang et al. 2008), brain endothelial cells (Hamzic et al. 2012), hepatocytes (Jayaraman et al. 2005), endometrial carcinoma cells (Mannelqvist et al. 2012), and erythroid progenitor cells (Miharada et al. 2005).

LCN2 has been implicated in diverse physiological and pathophysiological processes, including apoptosis, ion transport, inflammation, cell survival, tumorigenesis,

Published by Bioscientifica Ltd 
and atherosclerosis. Emerging evidence suggests that LCN2 is a novel adipokine that contributes to obesity and IR. In reproduction, it was found that serum LCN2 concentrations in pregnant women with preeclampsia were significantly different from those in healthy pregnant women, suggesting a possible role for LCN2 in the pathogenesis of preeclampsia (Stepan et al. 2010, Cemgil Arikan et al. 2011).

In women with PCOS, Cakal et al. (2011) found a significant increase in serum LCN2 levels compared with BMI-matched controls (Table 1). Two other groups, however, revealed that PCOS per se does not affect LCN2 levels (Panidis et al. 2010, Koiou et al. 2012). Instead, obesity is associated with elevated serum LCN2. Weight loss consequently induces a significant decrease in LCN2 levels in overweight/obese patients with PCOS.

\section{Chemerin}

Chemerin, also known as tazarotene-induced gene 2 (TIG2) or retinoic acid receptor responder 2 (RARRES2), is a novel chemoattractant protein identified as a natural ligand of orphan receptor ChemR23 in 2003 by the group of Parmentier and Communi (Wittamer et al. 2003). It is synthesized as an inactive precursor, prochemerin, and is then rapidly converted to its active form by proteolytic cleavage during inflammation.

Chemerin exerts its potent leukocyte chemoattractant properties on leukocyte populations through its receptor ChemR23, a G protein-coupled seven-transmembrane receptor, which is also known as chemokine-like receptor 1 (CMKLR1). ChemR23 is predominantly expressed by immature myeloid and plasmacytoid dendritic cells, monocytes/macrophages, and natural killer (NK) cells (Parolini et al. 2007). Two other G protein-coupled receptors (GPRs) have been reported to bind chemerin with high affinity, namely GPR1 (Barnea et al. 2008) and C-C chemokine receptor-like 2 (CCLR2; Zabel et al. 2008). GPR1 is most closely related to ChemR23, but the expression pattern of GPR1 is different from ChemR23, with the main expression of GPR1 in the liver, intestine, kidney, and adipose tissue. CCLR2 is expressed at high levels by lung endothelial cells and at lower levels by liver endothelium in vivo (Monnier et al. 2012). It has been suggested to increase local concentrations of bioactive chemerin to facilitate the interaction between chemerin and CMKLR1 on adjacent cells (Zabel et al. 2008, Monnier et al. 2012).

In addition to its function in immunity, chemerin also plays a role in adipogenesis, adipocyte metabolism, and glucose metabolism. Chemerin has been identified as a novel adipokine due to its high expression in white adipocytes (Goralski et al. 2007) and has been demonstrated to be associated with obesity, metabolic syndrome, and T2DM (Bozaoglu et al. 2007, Goralski et al. 2007, Chu et al. 2012, Yamawaki et al. 2012). Bozaoglu et al. (2007) reported that plasma chemerin concentrations are strongly associated with BMI, plasma TGs, and blood pressure. Chemerin can regulate insulin sensitivity and insulin secretion. Conversely, insulin induces chemerin release from adipocytes (Bauer et al. 2012).

In reproduction, it has been shown that chemerin is present in human cord blood (Mazaki-Tovi et al. 2012). Upregulated chemerin levels in the decidua likely contribute to NK cell accumulation and vascular remodeling during early pregnancy (Carlino et al. 2012). Garces et al. (2012) showed that chemerin is expressed in rat placenta and serum chemerin levels were significantly decreased as gestation progressed, suggesting that chemerin may be an important regulator of maternal-fetal metabolism and metabolic homeostasis during pregnancy.

In patients with PCOS, Tan et al. (2009) detected a significant increase in serum chemerin, subcutaneous, and omental adipose tissue chemerin mRNA level and protein expression. Additionally, treatment with metformin for 6 months markedly decreased serum chemerin levels in PCOS patients. In a $5 \alpha$-dihydrotestosterone-induced rat model, expression of chemerin and its ChemR23 receptor was significantly higher in the ovaries at both mRNA and protein levels (Wang et al. 2012b). Interestingly, chemerin can negatively regulate FSH-induced

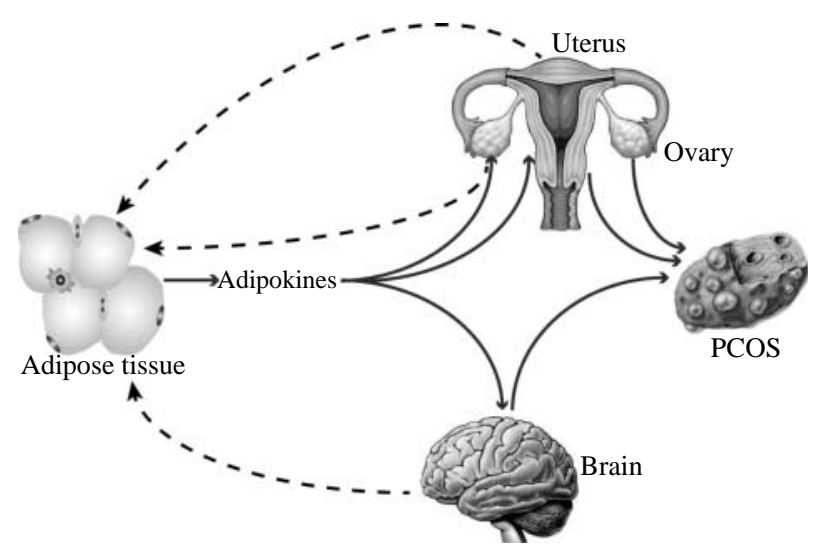

Figure 1

Schematic representation of a link between obesity and PCOS via adipokines. Adipokines, the secreted products of adipose tissue, can affect the brain, ovary, and endometrium and thus contribute to the pathology of PCOS. On the other hand, PCOS can also reciprocally influence the secretion of adipokines. Adipokines may thus act as a link between obesity and PCOS.

Published by Bioscientifica Ltd. 
follicular steroidogenesis and thus contribute to the pathogenesis of PCOS.

\section{Conclusions}

Obesity is highly present in PCOS patients and represents an independent and crucial risk factor for PCOS. Adipose tissue may communicate with the brain, ovaries, and uterus via adipokines, the adipose tissue-secreted products, to have an impact on both reproductive functions and metabolic features of women with PCOS (Fig. 1). Although the profile of most adipokines is still unknown in PCOS due to the conflicting data, the dysregulated adipokine levels in PCOS patients suggest that adipokines contribute to the pathology of PCOS. On the other hand, PCOS is also associated with higher central abdominal fat depots independent of obesity. Given the abnormal adipokine profile in women with PCOS irrespective of the presence or absence of obesity, PCOS may reciprocally influence the secretion of adipokines. Adipokines may thus serve as an endocrine link between obesity and PCOS, as shown in Fig. 1. It is also noteworthy that it was the circulating adipokine levels that were measured in most studies. However, it is still unknown whether all adipokines have endocrine actions. Circulating adipokine levels may not reflect the events occurring at the tissue levels by autocrine or paracrine mechanisms. Therefore, the use of circulating measurements is a limitation of most studies published to date. In addition, no adipokines have been identified so far as candidate molecules in genomic and proteomic studies of human omental adipose tissue in PCOS (Corton et al. 2008, Escobar-Morreale et al. 2008).

Our current understanding of the role for adipokines in PCOS is far from complete. The heterogeneity of clinical manifestations of PCOS patients makes this syndrome even challenging in the field of endocrinology, metabolism, and reproduction. Further work will thus be necessary to better understand the role of adipokines in reproductive functions that may act as a link between obesity and PCOS.

\section{Declaration of interest}

The authors declare that there is no conflict of interest that could be perceived as prejudicing the impartiality of the review reported.

\section{Funding}

This work was supported by the National Natural Science Foundation of China (grants numbers 81100398,81270943 ) and the Research Fund for the Doctoral Program of Higher Education (grants number 20100001120036).

\section{Acknowledgement}

The authors thank Dr Senfeng Zheng for the figure editing.

\section{References}

Adya R, Tan BK, Chen J \& Randeva HS 2008 Nuclear factor- $\kappa$ B induction by visfatin in human vascular endothelial cells: its role in MMP-2/9 production and activation. Diabetes Care 31 758-760. (doi:10.2337/ dc07-1544)

Agarwal SK, Vogel K, Weitsman SR \& Magoffin DA 1999 Leptin antagonizes the insulin-like growth factor-I augmentation of steroidogenesis in granulosa and theca cells of the human ovary. Journal of Clinical Endocrinology and Metabolism 84 1072-1076. (doi:10.1210/jc.84.3.1072)

Ahima RS, Prabakaran D, Mantzoros C, Qu D, Lowell B, Maratos-Flier E \& Flier JS 1996 Role of leptin in the neuroendocrine response to fasting. Nature 382 250-252. (doi:10.1038/382250a0)

Akdeniz N, Kuyumcuoglu U, Kale A, Arikan S, Kale E \& Erdemoglu M 2011 Resistin may not associate with gestational diabetes mellitus although insulin resistance. Clinical and Experimental Obstetrics \& Gynecology 38 236-238.

Ardawi MSM \& Rouzi AA 2005 Plasma adiponectin and insulin resistance in women with polycystic ovary syndrome. Fertility and Sterility $\mathbf{8 3}$ 1708-1716. (doi:10.1016/j.fertnstert.2004.11.077)

Azuma K, Oguchi S, Matsubara Y, Mamizuka T, Murata M, Kikuchi H, Watanabe K, Katsukawa F, Yamazaki H, Shimada A et al. 2004 Novel resistin promoter polymorphisms: association with serum resistin level in Japanese obese individuals. Hormone and Metabolic Research 36 564-570. (doi:10.1055/s-2004-825762)

Banerjee RR, Rangwala SM, Shapiro JS, Rich AS, Rhoades B, Qi Y, Wang J, Rajala MW, Pocai A, Scherer PE et al. 2004 Regulation of fasted blood glucose by resistin. Science 303 1195-1198. (doi:10.1126/science. 1092341)

Barnea G, Strapps W, Herrada G, Berman Y, Ong J, Kloss B, Axel R \& Lee KJ 2008 The genetic design of signaling cascades to record receptor activation. PNAS $\mathbf{1 0 5}$ 64-69. (doi:10.1073/pnas.0710 487105)

Bauer S, Bala M, Kopp A, Eisinger K, Schmid A, Schneider S, Neumeier M \& Buechler C 2012 Adipocyte chemerin release is induced by insulin without being translated to higher levels in vivo. European Journal of Clinical Investigation 42 1213-1220. (doi:10.1111/j.1365-2362.2012. 02713.x)

Bedaiwy MA 2005 Peritoneal fluid leptin is associated with chronic pelvic pain but not infertility in endometriosis patients. Human Reproduction 21 788-791. (doi:10.1093/humrep/dei376)

Bluher S \& Mantzoros CS 2007 Leptin in reproduction. Current Opinion in Endocrinology, Diabetes, and Obesity 14 458-464. (doi:10.1097/MED. 0b013e3282f1cfdc)

Bohler H, Mokshagundam S \& Winters SJ 2010 Adipose tissue and reproduction in women. Fertility and Sterility 94 795-825. (doi:10.1016/ j.fertnstert.2009.03.079)

Botella-Carretero JI, Luque-Ramirez M, Alvarez-Blasco F, Peromingo R, San Millan JL \& Escobar-Morreale HF 2008 The increase in serum visfatin after bariatric surgery in morbidly obese women is modulated by weight loss, waist circumference, and presence or absence of diabetes before surgery. Obesity Surgery 18 1000-1006. (doi:10.1007/ s11695-007-9369-7)

Bozaoglu K, Bolton K, McMillan J, Zimmet P, Jowett J, Collier G, Walder K \& Segal D 2007 Chemerin is a novel adipokine associated with obesity and metabolic syndrome. Endocrinology 148 4687-4694. (doi:10.1210/ en.2007-0175)

Brannian JD \& Hansen KA 2002 Leptin and ovarian folliculogenesis: implications for ovulation induction and ART outcomes. Seminars in Reproductive Medicine 20 103-112. (doi:10.1055/s-2002-32501) http://jme.endocrinology-journals.org DOI: 10.1530/JME-12-0247
() 2013 Society for Endocrinology Printed in Great Britain 
Bratt T, Ohlson S \& Borregaard N 1999 Interactions between neutrophil gelatinase-associated lipocalin and natural lipophilic ligands. Biochimica et Biophysica Acta 1472 262-269. (doi:10.1016/S03044165(99)00131-2)

Brewer CJ \& Balen AH 2010 The adverse effects of obesity on conception and implantation. Reproduction 140 347-364. (doi:10.1530/REP-090568)

Brzechffa PR, Jakimiuk AJ, Agarwal SK, Weitsman SR, Buyalos RP \& Magoffin DA 1996 Serum immunoreactive leptin concentrations in women with polycystic ovary syndrome. Journal of Clinical Endocrinology and Metabolism 81 4166-4169. (doi:10.1210/jc.81.11.4166)

Budak E, Fernandezsanchez M, Bellver J, Cervero A, Simon C \& Pellicer A 2006 Interactions of the hormones leptin, ghrelin, adiponectin, resistin, and PYY3-36 with the reproductive system. Fertility and Sterility 85 1563-1581. (doi:10.1016/j.fertnstert.2005.09.065)

Cakal E, Ozkaya M, Engin-Ustun Y \& Ustun Y 2011 Serum lipocalin-2 as an insulin resistance marker in patients with polycystic ovary syndrome. Journal of Endocrinological Investigation 34 97-100. (doi:10.3275/7077)

Campos DB, Palin MF, Bordignon V \& Murphy BD 2007 The 'beneficial' adipokines in reproduction and fertility. International Journal of Obesity 32 223-231. (doi:10.1038/sj.ijo.0803719)

Carlino C, Trotta E, Stabile H, Morrone S, Bulla R, Soriani A, Iannitto ML, Agostinis C, Mocci C, Minozzi M et al. 2012 Chemerin regulates NK cell accumulation and endothelial cell morphogenesis in the decidua during early pregnancy. Journal of Clinical Endocrinology and Metabolism 97 3603-3612. (doi:10.1210/jc.2012-1102)

Carmina E, Bucchieri S, Mansueto P, Rini G, Ferin M \& Lobo RA 2009 Circulating levels of adipose products and differences in fat distribution in the ovulatory and anovulatory phenotypes of polycystic ovary syndrome. Fertility and Sterility 91 1332-1335. (doi:10.1016/j.fertnstert. 2008.03.007)

Cemgil Arikan D, Ozkaya M, Adali E, Kilinc M, Coskun A, Ozer A \& Bilge F 2011 Plasma lipocalin-2 levels in pregnant women with pre-eclampsia, and their relation with severity of disease. Journal of Maternal-Fetal and Neonatal Medicine 24 291-296. (doi:10.3109/14767058.2010.487138)

Chan T-F, Chen Y-L, Chen H-H, Lee C-H, Jong S-B \& Tsai E-M 2007 Increased plasma visfatin concentrations in women with polycystic ovary syndrome. Fertility and Sterility 88 401-405. (doi:10.1016/j. fertnstert.2006.11.120)

Chang Y-C, Chang T-J, Lee W-J \& Chuang L-M 2010 The relationship of visfatin/pre-B-cell colony-enhancing factor/nicotinamide phosphoribosyltransferase in adipose tissue with inflammation, insulin resistance, and plasma lipids. Metabolism 59 93-99. (doi:10.1016/j.metabol. 2009.07.011)

Chang Y-H, Chang D-M, Lin K-C, Shin S-J \& Lee Y-J 2011 Visfatin in overweight/obesity, type 2 diabetes mellitus, insulin resistance, metabolic syndrome and cardiovascular diseases: a meta-analysis and systemic review. Diabetes/Metabolism Research and Reviews 27 515-527. (doi:10.1002/dmrr.1201)

Chapman IM, Wittert GA \& Norman RJ 1997 Circulating leptin concentrations in polycystic ovary syndrome: relation to anthropometric and metabolic parameters. Clinical Endocrinology 46 175-181. (doi:10.1046/j.1365-2265.1997.1200936.x)

Chen H, Charlat O, Tartaglia LA, Woolf EA, Weng X, Ellis SJ, Lakey ND, Culpepper J, Moore KJ, Breitbart RE et al. 1996 Evidence that the diabetes gene encodes the leptin receptor: identification of a mutation in the leptin receptor gene in $d b / d b$ mice. Cell 84 491-495. (doi:10. 1016/S0092-8674(00)81294-5)

Chen CC, Li TC, Li CI, Liu CS, Wang HJ \& Lin CC 2005 Serum resistin level among healthy subjects: Relationship to anthropometric and metabolic parameters. Metabolism 54 471-475. (doi:10.1016/j.metabol. 2004.10.015)

Choi KM, Kim JH, Cho GJ, Baik SH, Park HS \& Kim SM 2007 Effect of exercise training on plasma visfatin and eotaxin levels. European Journal of Endocrinology 157 437-442. (doi:10.1530/EJE-07-0127)
Choi JH, Rhee EJ, Kim KH, Woo HY, Lee WY \& Sung KC 2011 Plasma omentin-1 levels are reduced in non-obese women with normal glucose tolerance and polycystic ovary syndrome. European Journal of Endocrinology 165 789-796. (doi:10.1530/EJE-11-0375)

Chou SH, Chamberland JP, Liu X, Matarese G, Gao C, Stefanakis R, Brinkoetter MT, Gong H, Arampatzi K \& Mantzoros CS 2011 Leptin is an effective treatment for hypothalamic amenorrhea. PNAS 108 6585-6590. (doi:10.1073/pnas.1015674108)

Chu SH, Lee MK, Ahn KY, Im JA, Park MS, Lee DC, Jeon JY \& Lee JW 2012 Chemerin and adiponectin contribute reciprocally to metabolic syndrome. PLoS ONE 7 e34710. (doi:10.1371/journal.pone.0034710)

Clempson AM, Pollott GE, Brickell JS, Bourne NE, Munce N \& Wathes DC 2011 Evidence that leptin genotype is associated with fertility, growth, and milk production in Holstein cows. Journal of Daily Science $\mathbf{9 4}$ 3618-3628. (doi:10.3168/jds.2010-3626)

Corton M, Botella-Carretero JI, Lopez JA, Camafeita E, San Millan JL, Escobar-Morreale HF \& Peral B 2008 Proteomic analysis of human omental adipose tissue in the polycystic ovary syndrome using twodimensional difference gel electrophoresis and mass spectrometry. Human Reproduction 23 651-661. (doi:10.1093/humrep/dem380)

Denzel MS, Scimia MC, Zumstein PM, Walsh K, Ruiz-Lozano P \& Ranscht B 2010 T-cadherin is critical for adiponectin-mediated cardioprotection in mice. Journal of Clinical Investigation 120 4342-4352. (doi:10.1172/ JCI43464)

De Placido G, Alviggi C, Carravetta C, Pisaturo ML, Sanna V, Wilding M, Lord GM \& Matarese G 2001 The peritoneal fluid concentration of leptin is increased in women with peritoneal but not ovarian endometriosis. Human Reproduction 16 1251-1254. (doi:10.1093/ humrep/16.6.1251)

Diamanti-Kandarakis E \& Dunaif A 2012 Insulin resistance and the polycystic ovary syndrome revisited: an update on mechanisms and implications. Endocrine Reviews 33 981-1030. (doi:10.1210/er.20111034)

Donato J Jr, Cravo RM, Frazao R, Gautron L, Scott MM, Lachey J, Castro IA, Margatho LO, Lee S, Lee C et al. 2011 Leptin's effect on puberty in mice is relayed by the ventral premammillary nucleus and does not require signaling in Kiss1 neurons. Journal of Clinical Investigation 121 355-368. (doi:10.1172/JCI45106)

Dos Santos E, Serazin V, Morvan C, Torre A, Wainer R, de Mazancourt P \& Dieudonné M-N 2012 Adiponectin and leptin systems in human endometrium during window of implantation. Fertility and Sterility $\mathbf{9 7}$ 771-778.e771. (doi:10.1016/j.fertnstert.2011.12.042)

Elbein SC, Hoffman MD, Teng K, Leppert MF \& Hasstedt SJ 1999 A genomewide search for type 2 diabetes susceptibility genes in Utah Caucasians. Diabetes 48 1175-1182. (doi:10.2337/diabetes.48.5.1175)

El Orabi H, Ghalia AA, Khalifa A, Mahfouz H, El Shalkani A \& Shoieb N 1999 Serum leptin as an additional possible pathogenic factor in polycystic ovary syndrome. Clinical Biochemistry 32 71-75. (doi:10.1016/S00099120(98)00091-5)

Escobar-Morreale HF 2006 Adiponectin and resistin in PCOS: a clinical, biochemical and molecular genetic study. Human Reproduction 21 2257-2265. (doi:10.1093/humrep/del146)

Escobar-Morreale HF, Villuendas G, Botella-Carretero JI, Alvarez-Blasco F, Sanchon R, Luque-Ramirez M \& San Millan JL 2006 Adiponectin and resistin in PCOS: a clinical, biochemical and molecular genetic study. Human Reproduction 21 2257-2265. (doi:10.1093/humrep/del146)

Escobar-Morreale HF, Insenser M, Corton M, Millan JL \& Peral B 2008 Proteomics and genomics: a hypothesis-free approach to the study of the role of visceral adiposity in the pathogenesis of the polycystic ovary syndrome. Proteomics. Clinical Applications 2 444-455. (doi:10.1002/ prca.200780031)

Fan Y, Meng S, Wang Y, Cao J \& Wang C 2011 Visfatin/PBEF/Nampt induces EMMPRIN and MMP-9 production in macrophages via the NAMPT-MAPK (p38, ERK1/2)-NF- $\mathrm{B}$ signaling pathway. International Journal of Molecular Medicine 27 607-615. (doi:10.3892/ijmm.2011.621)

Published by Bioscientifica Ltd. 
Filippatos TD, Derdemezis CS, Kiortsis DN, Tselepis AD \& Elisaf MS 2007 Increased plasma levels of visfatin/pre-B cell colony-enhancing factor in obese and overweight patients with metabolic syndrome. Journal of Endocrinological Investigation 30 323-326.

Frydelund-Larsen L, Akerstrom T, Nielsen S, Keller P, Keller C \& Pedersen BK 2007 Visfatin mRNA expression in human subcutaneous adipose tissue is regulated by exercise. American Journal of Physiology. Endocrinology and Metabolism 292 E24-E31. (doi:10.1152/ajpendo. 00113.2006)

Fukuhara A, Matsuda M, Nishizawa M, Segawa K, Tanaka M, Kishimoto K, Matsuki Y, Murakami M, Ichisaka T, Murakami H et al. 2005 Visfatin: a protein secreted by visceral fat that mimics the effects of insulin. Science 307 426-430. (doi:10.1126/science.1097243)

Fukuhara A, Matsuda M, Nishizawa M, Segawa K, Tanaka M, Kishimoto K, Matsuki Y, Murakami M, Ichisaka T, Murakami H et al. 2007 Retraction. Science 318 565. (doi:10.1126/science.318.5850.565b)

Gao L, Zhang Y, Cui Y, Jiang Y, Wang X \& Liu J 2012 Association of the T45G and G276T polymorphisms in the adiponectin gene with PCOS: a meta-analysis. Gynecological Endocrinology 28 106-110. (doi:10.3109/ 09513590.2010.508543)

Garces MF, Sanchez E, Acosta BJ, Angel E, Ruiz AI, Rubio-Romero JA, Dieguez C, Nogueiras R \& Caminos JE 2012 Expression and regulation of chemerin during rat pregnancy. Placenta 33 373-378. (doi:10.1016/j. placenta.2012.02.007)

Gavrila A, Peng CK, Chan JL, Mietus JE, Goldberger AL \& Mantzoros CS 2003 Diurnal and ultradian dynamics of serum adiponectin in healthy men: comparison with leptin, circulating soluble leptin receptor, and cortisol patterns. Journal of Clinical Endocrinology and Metabolism $\mathbf{8 8}$ 2838-2843. (doi:10.1210/jc.2002-021721)

Gennarelli G, Holte J, Wide L, Berne C \& Lithell H 1998 Is there a role for leptin in the endocrine and metabolic aberrations of polycystic ovary syndrome? Human Reproduction 13 535-541. (doi:10.1093/humrep/13. 3.535)

Gerrits AJ, Gitz E, Koekman CA, Visseren FL, van Haeften TW \& Akkerman JW 2012 Induction of insulin resistance by the adipokines resistin, leptin, plasminogen activator inhibitor-1 and retinol binding protein 4 in human megakaryocytes. Haematologica 97 1149-1157. (doi:10.3324/haematol.2011.054916)

Goodarzi MO, Dumesic DA, Chazenbalk G \& Azziz R 2011 Polycystic ovary syndrome: etiology, pathogenesis and diagnosis. Nature Reviews. Endocrinology 7 219-231. (doi:10.1038/nrendo.2010.217)

Goralski KB, McCarthy TC, Hanniman EA, Zabel BA, Butcher EC, Parlee SD, Muruganandan S \& Sinal CJ 2007 Chemerin, a novel adipokine that regulates adipogenesis and adipocyte metabolism. Journal of Biological Chemistry 282 28175-28188. (doi:10.1074/jbc.M700793200)

Gorska E, Popko K, Stelmaszczyk-Emmel A, Ciepiela O, Kucharska A \& Wasik M 2010 Leptin receptors. European Journal of Medical Research 15 (Suppl 2) 50-54.

Graham TE, Yang Q, Bluher M, Hammarstedt A, Ciaraldi TP, Henry RR, Wason CJ, Oberbach A, Jansson PA, Smith U et al. 2006 Retinol-binding protein 4 and insulin resistance in lean, obese, and diabetic subjects. New England Journal of Medicine 354 2552-2563. (doi:10.1056/ NEJMoa054862)

Guducu N, Isci H, Gormus U, Yigiter AB \& Dunder I 2012 Serum visfatin levels in women with polycystic ovary syndrome. Gynecological Endocrinology 28 619-623. (doi:10.3109/09513590.2011.650749)

Haider DG, Schindler K, Schaller G, Prager G, Wolzt M \& Ludvik B 2006 Increased plasma visfatin concentrations in morbidly obese subjects are reduced after gastric banding. Journal of Clinical Endocrinology and Metabolism 91 1578-1581. (doi:10.1210/jc.2005-2248)

Hamzic N, Blomqvist A \& Nilsberth C 2013 Immune-induced expression of lipocalin-2 in brain endothelial cells: relationship to interleukin-6, cyclooxygenase- 2 and the febrile response. Journal of Neuroendocrinology. (doi:10.1111/jne.12000)

Hanson RL, Ehm MG, Pettitt DJ, Prochazka M, Thompson DB, Timberlake D, Foroud T, Kobes S, Baier L, Burns DK et al. 1998 An autosomal genomic scan for loci linked to type II diabetes mellitus and body-mass index in Pima Indians. American Journal of Human Genetics 63 1130-1138. (doi:10.1086/302061)

Heilbronn LK, Rood J, Janderova L, Albu JB, Kelley DE, Ravussin E \& Smith SR 2004 Relationship between serum resistin concentrations and insulin resistance in nonobese, obese, and obese diabetic subjects. Journal of Clinical Endocrinology and Metabolism 89 1844-1848. (doi:10.1210/jc.2003-031410)

Hug C \& Lodish HF 2005 Medicine. Visfatin: a new adipokine. Science 307 366-367. (doi:10.1126/science.1106933)

Hug C, Wang J, Ahmad NS, Bogan JS, Tsao TS \& Lodish HF 2004 T-cadherin is a receptor for hexameric and high-molecular-weight forms of Acrp30/adiponectin. PNAS 101 10308-10313. (doi:10.1073/pnas. 0403382101)

Israel D \& Chua S Jr 2010 Leptin receptor modulation of adiposity and fertility. Trends in Endocrinology and Metabolism 21 10-16. (doi:10.1016/ j.tem.2009.07.004)

Jacques C, Holzenberger M, Mladenovic Z, Salvat C, Pecchi E, Berenbaum F \& Gosset M 2012 Proinflammatory actions of visfatin/nicotinamide phosphoribosyltransferase (Nampt) involve regulation of insulin signaling pathway and Nampt enzymatic activity. Journal of Biological Chemistry 287 15100-15108. (doi:10.1074/jbc.M112.350215)

Jayaraman A, Roberts KA, Yoon J, Yarmush DM, Duan X, Lee K \& Yarmush ML 2005 Identification of neutrophil gelatinase-associated lipocalin (NGAL) as a discriminatory marker of the hepatocyte-secreted protein response to IL-1 $\beta$ : a proteomic analysis. Biotechnology and Bioengineering 91 502-515. (doi:10.1002/bit.20535)

Kadowaki T \& Yamauchi T 2005 Adiponectin and adiponectin receptors. Endocrine Reviews 26 439-451. (doi:10.1210/er.2005-0005)

Kadowaki T, Yamauchi T, Kubota N, Hara K, Ueki K \& Tobe K 2006 Adiponectin and adiponectin receptors in insulin resistance, diabetes, and the metabolic syndrome. Journal of Clinical Investigation 116 1784-1792. (doi:10.1172/JCI29126)

Kazama K, Usui T, Okada M, Hara Y \& Yamawaki H 2012 Omentin plays an anti-inflammatory role through inhibition of TNF- $\alpha$-induced superoxide production in vascular smooth muscle cells. European Journal of Pharmacology 686 116-123. (doi:10.1016/j.ejphar.2012.04.033)

Kielstein JT, Becker B, Graf S, Brabant G, Haller H \& Fliser D 2003 Increased resistin blood levels are not associated with insulin resistance in patients with renal disease. American Journal of Kidney Diseases 42 62-66. (doi:10.1016/S0272-6386(03)00409-8)

Kim KH, Lee K, Moon YS \& Sul HS 2001 A cysteine-rich adipose tissuespecific secretory factor inhibits adipocyte differentiation. Journal of Biological Chemistry 276 11252-11256. (doi:10.1074/jbc.C100028200)

Kim ST, Marquard K, Stephens S, Louden E, Allsworth J \& Moley KH 2011 Adiponectin and adiponectin receptors in the mouse preimplantation embryo and uterus. Human Reproduction 26 82-95. (doi:10.1093/ humrep/deq292)

Kjeldsen L, Johnsen AH, Sengelov H \& Borregaard N 1993 Isolation and primary structure of NGAL, a novel protein associated with human neutrophil gelatinase. Journal of Biological Chemistry 268 10425-10432.

Koiou E, Tziomalos K, Katsikis I, Kandaraki EA, Kalaitzakis E, Delkos D, Vosnakis C \& Panidis D 2012 Weight loss significantly reduces serum lipocalin-2 levels in overweight and obese women with polycystic ovary syndrome. Gynecological Endocrinology 28 20-24. (doi:10.3109/ 09513590.2011.588745)

Kowalska I, Straczkowski M, Nikolajuk A, Adamska A, Karczewska-Kupczewska M, Otziomek E, Wolczynski S \& Gorska M 2007 Serum visfatin in relation to insulin resistance and markers of hyperandrogenism in lean and obese women with polycystic ovary syndrome. Human Reproduction 22 1824-1829. (doi:10.1093/humrep/ dem118)

Krzyzanowska K, Mittermayer F, Krugluger W, Kopp HP \& Schernthaner G 2006 Increase in visfatin after weight loss induced by gastroplastic surgery. Obesity 14 1886-1889. (doi:10.1038/oby.2006.219) 
Kubota N, Yano W, Kubota T, Yamauchi T, Itoh S, Kumagai H, Kozono H, Takamoto I, Okamoto S, Shiuchi T et al. 2007 Adiponectin stimulates AMP-activated protein kinase in the hypothalamus and increases food intake. Cell Metabolism 6 55-68. (doi:10.1016/j.cmet.2007.06.003)

Kunnari A, Ukkola O \& Kesaniemi Y 2005 Resistin polymorphisms are associated with cerebrovascular disease in Finnish type 2 diabetic patients. Diabetic Medicine 22 583-589. (doi:10.1111/j.1464-5491.2005. 01480.x)

Lagaly D, Aad P, Grado-Ahuir J, Hulsey L \& Spicer L 2008 Role of adiponectin in regulating ovarian theca and granulose cell function. Molecular and Cellular Endocrinology 284 38-45. (doi:10.1016/j.mce. 2008.01.007)

Lajunen TK, Purhonen AK, Haapea M, Ruokonen A, Puukka K, Hartikainen AL, Savolainen MJ, Morin-Papunen L, Tapanainen JS, Franks S et al. 2012 Full-length visfatin levels are associated with inflammation in women with polycystic ovary syndrome. European Journal of Clinical Investigation 42 321-328. (doi:10.1111/j.1365-2362. 2011.02586.x)

Laughlin GA, Morales AJ \& Yen SS 1997 Serum leptin levels in women with polycystic ovary syndrome: the role of insulin resistance/hyperinsulinemia. Journal of Clinical Endocrinology and Metabolism 82 1692-1696. (doi:10.1210/jc.82.6.1692)

Lecke SB, Mattei F, Morsch DM \& Spritzer PM 2011 Abdominal subcutaneous fat gene expression and circulating levels of leptin and adiponectin in polycystic ovary syndrome. Fertility and Sterility $\mathbf{9 5}$ 2044-2049. (doi:10.1016/j.fertnstert.2011.02.041)

Ledoux S, Campos DB, Lopes FL, Dobias-Goff M, Palin MF \& Murphy BD 2006 Adiponectin induces periovulatory changes in ovarian follicular cells. Endocrinology 147 5178-5186. (doi:10.1210/en.2006-0679)

Lee GH, Proenca R, Montez JM, Carroll KM, Darvishzadeh JG, Lee JI \& Friedman JM 1996 Abnormal splicing of the leptin receptor in diabetic mice. Nature 379 632-635. (doi:10.1038/379632a0)

Lee JK, Schnee J, Pang M, Wolfert M, Baum LG, Moremen KW \& Pierce M 2001 Human homologs of the Xenopus oocyte cortical granule lectin XL35. Glycobiology 11 65-73. (doi:10.1093/glycob/11.1.65)

Lee J, Chan J, Yiannakouris N, Kontogianni M, Estrada E, Seip R, Orlova C \& Mantzoros C 2003 Circulating resistin levels are not associated with obesity or insulin resistance in humans and are not regulated by fasting or leptin administration: cross-sectional and interventional studies in normal, insulin-resistant, and diabetic subjects. Journal of Clinical Endocrinology and Metabolism 88 4848-4856. (doi:10.1210/jc.2003-030519)

Lim SS, Davies MJ, Norman RJ \& Moran LJ 2012 Overweight, obesity and central obesity in women with polycystic ovary syndrome: a systematic review and meta-analysis. Human Reproduction Update 18 618-637. (doi:10.1093/humupd/dms030)

Liu YH, Tsai EM, Chen YL, Chen HS, Chen YC, Wu LC, Lee CH, Jong SB \& Chan TF 2006 Serum adiponectin levels increase after human chorionic gonadotropin treatment during in vitro fertilization. Gynecologic and Obstetric Investigation 62 61-65. (doi:10.1159/000092260)

Lu M, Tang Q, Olefsky JM, Mellon PL \& Webster NJ 2008 Adiponectin activates adenosine monophosphate-activated protein kinase and decreases luteinizing hormone secretion in L $\beta \mathrm{T} 2$ gonadotropes. Molecular Endocrinology 22 760-771. (doi:10.1210/me.2007-0330)

Luo XH, Guo LJ, Yuan LQ, Xie H, Zhou HD, Wu XP \& Liao EY 2005 Adiponectin stimulates human osteoblasts proliferation and differentiation via the MAPK signaling pathway. Experimental Cell Research 309 99-109. (doi:10.1016/j.yexcr.2005.05.021)

Machell NH, Blaschuk OW \& Farookhi R 2000 Developmental expression and distribution of N- and E-cadherin in the rat ovary. Biology of Reproduction 63 797-804. (doi:10.1095/biolreprod63.3.797)

Mahde A, Shaker M \& Al-Mashhadani Z 2009 Study of omentin1 and other adipokines and hormones in PCOS patients. Oman Medical Journal 24 108-118. (doi:10.5001/omj.2009.25)

Maillard V, Froment P, Rame C, Uzbekova S, Elis S \& Dupont J 2011 Expression and effect of resistin on bovine and rat granulosa cell steroidogenesis and proliferation. Reproduction 141 467-479. (doi:10.1530/REP-10-0419)

Majuri A, Santaniemi M, Rautio K, Kunnari A, Vartiainen J, Ruokonen A, Kesaniemi YA, Tapanainen JS, Ukkola O \& Morin-Papunen L 2007 Rosiglitazone treatment increases plasma levels of adiponectin and decreases levels of resistin in overweight women with PCOS: a randomized placebo-controlled study. European Journal of Endocrinology 156 263-269. (doi:10.1530/eje.1.02331)

Mannelqvist M, Stefansson IM, Wik E, Kusonmano K, Raeder MB, Oyan AM, Kalland KH, Moses MA, Salvesen HB \& Akslen LA 2012 Lipocalin 2 expression is associated with aggressive features of endometrial cancer. BMC Cancer 12 169. (doi:10.1186/1471-2407-12-169)

Manneras-Holm L, Leonhardt H, Kullberg J, Jennische E, Oden A, Holm G, Hellstrom M, Lonn L, Olivecrona G, Stener-Victorin E et al. 2011 Adipose tissue has aberrant morphology and function in PCOS: enlarged adipocytes and low serum adiponectin, but not circulating sex steroids, are strongly associated with insulin resistance. Journal of Clinical Endocrinology and Metabolism 96 E304-E311. (doi:10.1210/jc. 2010-1290)

Mantzoros CS, Dunaif A \& Flier JS 1997 Leptin concentrations in the polycystic ovary syndrome. Journal of Clinical Endocrinology and Metabolism 82 1687-1691. (doi:10.1210/jc.82.6.1687)

Marciniak A, Nawrocka-Rutkowska J, Brodowska A, Sienkiewicz R, Szydlowska I \& Starczewski A 2009 Leptin concentrations in patients with polycystic ovary syndrome before and after metformin treatment depending on insulin resistance, body mass index and androgen concentrations - introductory report. Folia Histochemica et Cytobiologica 47 323-328. (doi:10.2478/v10042-009-0032-0)

Marin Bivens CL \& Olster DH 1997 Abnormal estrous cyclicity and behavioral hyporesponsiveness to ovarian hormones in genetically obese Zucker female rats. Endocrinology 138 143-148. (doi:10.1210/en. 138.1.143)

Masuzaki H, Ogawa Y, Sagawa N, Hosoda K, Matsumoto T, Mise H, Nishimura H, Yoshimasa Y, Tanaka I, Mori T et al. 1997 Nonadipose tissue production of leptin: leptin as a novel placenta-derived hormone in humans. Nature Medicine 3 1029-1033. (doi:10.1038/nm0997-1029)

Mazaki-Tovi S, Kasher-Meron M, Hemi R, Haas J, Gat I, Lantsberg D, Hendler I \& Kanety H 2012 Chemerin is present in human cord blood and is positively correlated with birthweight. American Journal of Obstetrics and Gynecology 207 412.e1-412.e10. (doi:10.1016/j.ajog. 2012.08.008)

Michalakis KG \& Segars JH 2010 The role of adiponectin in reproduction: from polycystic ovary syndrome to assisted reproduction. Fertility and Sterility 94 1949-1957. (doi:10.1016/j.fertnstert.2010.05.010)

Micic D, Macut D, Popovic V, Sumarac-Dumanovic M, Kendereski A, Colic M, Dieguez C \& Casanueva FF 1997 Leptin levels and insulin sensitivity in obese and non-obese patients with polycystic ovary syndrome. Gynecological Endocrinology 11 315-320. (doi:10.3109/ 09513599709152554)

Miharada K, Hiroyama T, Sudo K, Nagasawa T \& Nakamura Y 2005 Lipocalin 2 functions as a negative regulator of red blood cell production in an autocrine fashion. FASEB Journal 19 1881-1883.

Mix H, Manns MP, Wagner S, Widjaja A \& Brabant G 1999 Expression of leptin and its receptor in the human stomach. Gastroenterology 117509. (doi:10.1053/gast.1999.0029900509b)

Monnier J, Lewen S, O’Hara E, Huang K, Tu H, Butcher EC \& Zabel BA 2012 Expression, regulation, and function of atypical chemerin receptor CCRL2 on endothelial cells. Journal of Immunology 189 956-967. (doi:10.4049/jimmunol.1102871)

Moreno-Navarrete JM, Catalan V, Ortega F, Gomez-Ambrosi J, Ricart W, Fruhbeck G \& Fernandez-Real JM 2010 Circulating omentin concentration increases after weight loss. Nutrition and Metabolism 727. (doi:10.1186/1743-7075-7-27)

Morin-Papunen LC, Koivunen RM, Tomas C, Ruokonen A \& Martikainen HK 1998 Decreased serum leptin concentrations during metformin therapy in obese women with polycystic ovary syndrome. 
Journal of Clinical Endocrinology and Metabolism 83 2566-2568. (doi:10.1210/jc.83.7.2566)

Morris DL \& Rui L 2009 Recent advances in understanding leptin signaling and leptin resistance. American Journal of Physiology. Endocrinology and Metabolism 297 E1247-E1259. (doi:10.1152/ajpendo.00274.2009)

Moschen AR, Kaser A, Enrich B, Mosheimer B, Theurl M, Niederegger H \& Tilg H 2007 Visfatin, an adipocytokine with proinflammatory and immunomodulating properties. Journal of Immunology 178 1748-1758.

Munir I, Yen HW, Baruth T, Tarkowski R, Azziz R, Magoffin DA \& Jakimiuk AJ 2005 Resistin stimulation of $17 \alpha$-hydroxylase activity in ovarian theca cells in vitro: relevance to polycystic ovary syndrome. Journal of Clinical Endocrinology and Metabolism 90 4852-4857. (doi:10. 1210/jc.2004-2152)

Muse ED, Obici S, Bhanot S, Monia BP, McKay RA, Rajala MW, Scherer PE \& Rossetti L 2004 Role of resistin in diet-induced hepatic insulin resistance. Journal of Clinical Investigation 114 232-239.

Myers MG, Leibel RL, Seeley RJ \& Schwartz MW 2010 Obesity and leptin resistance: distinguishing cause from effect. Trends in Endocrinology and Metabolism 21 643-651. (doi:10.1016/j.tem.2010.08.002)

O'Connor A, Phelan N, Tun TK, Boran G, Gibney J \& Roche HM 2010 Highmolecular-weight adiponectin is selectively reduced in women with polycystic ovary syndrome independent of body mass index and severity of insulin resistance. Journal of Clinical Endocrinology and Metabolism 95 1378-1385. (doi:10.1210/jc.2009-1557)

Ogura K, Irahara M, Kiyokawa M, Tezuka M, Matsuzaki T, Yasui T, Kamada M \& Aono T 2001 Effects of leptin on secretion of LH and FSH from primary cultured female rat pituitary cells. European Journal of Endocrinology 144 653-658. (doi:10.1530/eje.0.1440653)

Olszanecka-Glinianowicz M, Kuglin D, Dabkowska-Huc A \& Skalba P 2011 Serum adiponectin and resistin in relation to insulin resistance and markers of hyperandrogenism in lean and obese women with polycystic ovary syndrome. European Journal of Obstetrics, Gynecology, and Reproductive Biology 154 51-56. (doi:10.1016/j.ejogrb.2010.08.022)

Olszanecka-Glinianowicz M, Madej P, Zdun D, Bozentowicz-Wikarek M, Sikora J, Chudek J \& Skalba P 2012 Are plasma levels of visfatin and retinol-binding protein 4 (RBP4) associated with body mass, metabolic and hormonal disturbances in women with polycystic ovary syndrome? European Journal of Obstetrics, Gynecology, and Reproductive Biology 162 55-61. (doi:10.1016/j.ejogrb.2012.01.026)

Orio F 2003 Adiponectin levels in women with polycystic ovary syndrome. Journal of Clinical Endocrinology and Metabolism 88 2619-2623. (doi:10.1210/jc.2002-022033)

Orvieto R, Shuhat V, Liberty G, Homburg R, Anteby EY, Nahum R, Rabinson J \& Meltcer S 2010 Serum retinol-binding protein-4 levels in polycystic ovary syndrome patients undergoing controlled ovarian hyperstimulation for in-vitro fertilization cycle. Clinical and Experimental Obstetrics \& Gynecology 37 100-104.

Ouchi N, Kobayashi H, Kihara S, Kumada M, Sato K, Inoue T, Funahashi T \& Walsh K 2004 Adiponectin stimulates angiogenesis by promoting crosstalk between AMP-activated protein kinase and Akt signaling in endothelial cells. Journal of Biological Chemistry 279 1304-1309. (doi:10. 1074/jbc.M310389200)

Ozkaya M, Cakal E, Ustun Y \& Engin-Ustun Y 2010 Effect of metformin on serum visfatin levels in patients with polycystic ovary syndrome. Fertility and Sterility 93 880-884. (doi:10.1016/j.fertnstert.2008.10.058)

Pagano C 2006 Reduced plasma visfatin/pre-B cell colony-enhancing factor in obesity is not related to insulin resistance in humans. Journal of Clinical Endocrinology and Metabolism 91 3165-3170. (doi:10.1210/jc. 2006-0361)

Pajvani UB, Hawkins M, Combs TP, Rajala MW, Doebber T, Berger JP, Wagner JA, Wu M, Knopps A, Xiang AH et al. 2004 Complex distribution, not absolute amount of adiponectin, correlates with thiazolidinedione-mediated improvement in insulin sensitivity. Journal of Biological Chemistry 279 12152-12162. (doi:10.1074/jbc. M311113200)
Pan HY, Guo L \& Li Q 2010 Changes of serum omentin-1 levels in normal subjects and in patients with impaired glucose regulation and with newly diagnosed and untreated type 2 diabetes. Diabetes Research and Clinical Practice 88 29-33. (doi:10.1016/j.diabres.2010.01.013)

Panidis DK, Rousso DH, Matalliotakis IM, Kourtis AI, Stamatopoulos P \& Koumantakis E 2000 The influence of long-term administration of conjugated estrogens and antiandrogens to serum leptin levels in women with polycystic ovary syndrome. Gynecological Endocrinology 14 169-172. (doi:10.3109/09513590009167678)

Panidis D, Koliakos G, Kourtis A, Farmakiotis D, Mouslech T \& Rousso D 2004 Serum resistin levels in women with polycystic ovary syndrome. Fertility and Sterility 81 361-366. (doi:10.1016/j.fertnstert.2003.06.021)

Panidis D, Farmakiotis D, Rousso D, Katsikis I, Delkos D, Piouka A, Gerou S \& Diamanti-Kandarakis E 2008 Plasma visfatin levels in normal weight women with polycystic ovary syndrome. European Journal of Internal Medicine 19 406-412. (doi:10.1016/j.ejim.2007.05.014)

Panidis D, Tziomalos K, Koiou E, Kandaraki EA, Tsourdi E, Delkos D, Kalaitzakis E \& Katsikis I 2010 The effects of obesity and polycystic ovary syndrome on serum lipocalin-2 levels: a cross-sectional study. Reproductive Biology and Endocrinology 8 151. (doi:10.1186/1477-78278-151)

Parolini S, Santoro A, Marcenaro E, Luini W, Massardi L, Facchetti F, Communi D, Parmentier M, Majorana A, Sironi M et al. 2007 The role of chemerin in the colocalization of NK and dendritic cell subsets into inflamed tissues. Blood 109 3625-3632. (doi:10.1182/blood-2006-08038844)

Pehlivanov B \& Mitkov M 2009 Serum leptin levels correlate with clinical and biochemical indices of insulin resistance in women with polycystic ovary syndrome. European Journal of Contraception and Reproductive Health Care 14 153-159. (doi:10.1080/13625180802549962)

Pfutzner A, Langenfeld M, Kunt T, Lobig M \& Forst T 2003 Evaluation of human resistin assays with serum from patients with type 2 diabetes and different degrees of insulin resistance. Clinical Laboratory 49 571-576.

Pietilainen KH, Kannisto K, Korsheninnikova E, Rissanen A, Kaprio J, Ehrenborg E, Hamsten A \& Yki-Jarvinen H 2006 Acquired obesity increases CD68 and tumor necrosis factor- $\alpha$ and decreases adiponectin gene expression in adipose tissue: a study in monozygotic twins. Journal of Clinical Endocrinology and Metabolism 91 2776-2781. (doi:10.1210/jc.2005-2848)

Pinhas-Hamiel O, Singer S, Pilpel N, Koren I, Boyko V, Hemi R, Pariente C \& Kanety H 2009 Adiponectin levels in adolescent girls with polycystic ovary syndrome (PCOS). Clinical Endocrinology 71 823-827. (doi:10.1111/j.1365-2265.2009.03604.x)

Plati E, Kouskouni E, Malamitsi-Puchner A, Boutsikou M, Kaparos G \& Baka S 2010 Visfatin and leptin levels in women with polycystic ovaries undergoing ovarian stimulation. Fertility and Sterility 94 1451-1456. (doi:10.1016/j.fertnstert.2009.04.055)

Psilopanagioti A, Papadaki H, Kranioti EF, Alexandrides TK \& Varakis JN 2009 Expression of adiponectin and adiponectin receptors in human pituitary gland and brain. Neuroendocrinology 89 38-47. (doi:10.1159/ 000151396)

Pusalkar M, Meherji P, Gokral J, Savardekar L, Chinnaraj S \& Maitra A 2010 Obesity and polycystic ovary syndrome: association with androgens, leptin and its genotypes. Gynecological Endocrinology 26 874-882. (doi:10.3109/09513590.2010.487586)

Rodriguez-Pacheco F, Martinez-Fuentes AJ, Tovar S, Pinilla L, Tena-Sempere M, Dieguez C, Castano JP \& Malagon MM 2006 Regulation of pituitary cell function by adiponectin. Endocrinology 148 401-410. (doi:10.1210/en.2006-1019)

Romacho T, Azcutia V, Vázquez-Bella M, Matesanz N, Cercas E, Nevado J, Carraro R, Rodríguez-Mañas L, Sánchez-Ferrer CF \& Peiró C 2009 Extracellular PBEF/NAMPT/visfatin activates pro-inflammatory signalling in human vascular smooth muscle cells through nicotinamide phosphoribosyltransferase activity. Diabetologia 52 2455-2463. (doi:10.1007/s00125-009-1509-2) 
Rouru J, Anttila L, Koskinen P, Penttila TA, Irjala K, Huupponen R \& Koulu M 1997 Serum leptin concentrations in women with polycystic ovary syndrome. Journal of Clinical Endocrinology and Metabolism $\mathbf{8 2}$ 1697-1700. (doi:10.1210/jc.82.6.1697)

Sagsoz N, Orbak Z, Noyan V, Yucel A, Ucar B \& Yildiz L 2009 The effects of oral contraceptives including low-dose estrogen and drospirenone on the concentration of leptin and ghrelin in polycystic ovary syndrome. Fertility and Sterility 92 660-666. (doi:10.1016/j.fertnstert.2008.07.008)

Sahu A 2004 Minireview: a hypothalamic role in energy balance with special emphasis on leptin. Endocrinology 145 2613-2620. (doi:10.1210/ en.2004-0032)

Samal B, Sun Y, Stearns G, Xie C, Suggs S \& McNiece I 1994 Cloning and characterization of the cDNA encoding a novel human pre-B-cell colony-enhancing factor. Molecular and Cellular Biology 14 1431-1437.

Sanchez-Solana B, Laborda J \& Baladron V 2012 Mouse resistin modulates adipogenesis and glucose uptake in 3T3-L1 preadipocytes through the ROR1 receptor. Molecular Endocrinology 26 110-127. (doi:10.1210/me.2011-1027)

Schwartz DR \& Lazar MA 2011 Human resistin: found in translation from mouse to man. Trends in Endocrinology and Metabolism 22 259-265. (doi:10.1016/j.tem.2011.03.005)

Senn JJ, Klover PJ, Nowak IA, Zimmers TA, Koniaris LG, Furlanetto RW \& Mooney RA 2003 Suppressor of cytokine signaling-3 (SOCS-3), a potential mediator of interleukin-6-dependent insulin resistance in hepatocytes. Journal of Biological Chemistry 278 13740-13746. (doi:10.1074/jbc.M210689200)

Seow KM 2004 Serum and follicular resistin levels in women with polycystic ovarian syndrome during IVF-stimulated cycles. Human Reproduction 20 117-121. (doi:10.1093/humrep/deh589)

Seow KM, Juan CC, Ho LT, Hsu YP, Lin YH, Huang LW \& Hwang JL 2007 Adipocyte resistin mRNA levels are down-regulated by laparoscopic ovarian electrocautery in both obese and lean women with polycystic ovary syndrome. Human Reproduction 22 1100-1106. (doi:10.1093/ humrep/del489)

Seow KM, Hwang JL, Wang PH, Ho LT \& Juan CC 2011 Expression of visfatin mRNA in peripheral blood mononuclear cells is not correlated with visfatin mRNA in omental adipose tissue in women with polycystic ovary syndrome. Human Reproduction 26 2869-2873. (doi:10.1093/humrep/der267)

Shaker M, Mashhadani ZI \& Mehdi AA 2010 Effect of treatment with metformin on omentin-1, ghrelin and other biochemical, clinical features in PCOS patients. Oman Medical Journal 25 289-293. (doi:10.5001/omj.2010.84)

Shen YH, Zhang L, Gan Y, Wang X, Wang J, LeMaire SA, Coselli JS \& Wang XL 2006 Up-regulation of PTEN (phosphatase and tensin homolog deleted on chromosome ten) mediates p38 MAPK stress signal-induced inhibition of insulin signaling. A cross-talk between stress signaling and insulin signaling in resistin-treated human endothelial cells. Journal of Biological Chemistry 281 7727-7736. (doi:10.1074/jbc.M511105200)

Shin H-Y, Lee D-C \& Lee J-W 2011 Adiponectin in women with polycystic ovary syndrome. Korean Journal of Family Medicine 32 243. (doi:10.4082/ kjfm.2011.32.4.243)

Silha JV, Krsek M, Skrha JV, Sucharda P, Nyomba BL \& Murphy LJ 2003 Plasma resistin, adiponectin and leptin levels in lean and obese subjects: correlations with insulin resistance. European Journal of Endocrinology 149 331-335. (doi:10.1530/eje.0.1490331)

Sir-Petermann T, Piwonka V, Perez F, Maliqueo M, Recabarren SE \& Wildt L 1999 Are circulating leptin and luteinizing hormone synchronized in patients with polycystic ovary syndrome? Human Reproduction 14 1435-1439. (doi:10.1093/humrep/14.6.1435)

Smith-Kirwin SM, O'Connor DM, De Johnston J, Lancey ED, Hassink SG \& Funanage VL 1998 Leptin expression in human mammary epithelial cells and breast milk. Journal of Clinical Endocrinology and Metabolism $\mathbf{8 3}$ 1810-1813. (doi:10.1210/jc.83.5.1810)
Sopher AB, Gerken AT, Blaner WS, Root JM, McMahon DJ \& Oberfield SE 2012 Metabolic manifestations of polycystic ovary syndrome in nonobese adolescents: retinol-binding protein 4 and ectopic fat deposition. Fertility and Sterility 97 1009-1015. (doi:10.1016/j.fertnstert.2012.01.111)

de Souza Batista CM, Yang RZ, Lee MJ, Glynn NM, Yu DZ, Pray J, Ndubuizu K, Patil S, Schwartz A, Kligman M et al. 2007 Omentin plasma levels and gene expression are decreased in obesity. Diabetes $\mathbf{5 6}$ 1655-1661. (doi:10.2337/db06-1506)

Spicer LJ, Schreiber NB, Lagaly DV, Aad PY, Douthit LB \& Grado-Ahuir JA 2011 Effect of resistin on granulosa and theca cell function in cattle. Animal Reproduction Science 124 19-27. (doi:10.1016/j.anireprosci.2011.01.005)

Spranger J, Mohlig M, Wegewitz U, Ristow M, Pfeiffer AFH, Schill T, Schlosser HW, Brabant G \& Schofl C 2004 Adiponectin is independently associated with insulin sensitivity in women with polycystic ovary syndrome. Clinical Endocrinology 61 738-746. (doi:10.1111/j. 1365-2265.2004.02159.x)

Stepan H, Philipp A, Reiche M, Klostermann K, Schrey S, Reisenbuchler C, Lossner U, Kratzsch J, Bluher M, Stumvoll M et al. 2010 Serum levels of the adipokine lipocalin-2 are increased in preeclampsia. Journal of Endocrinological Investigation 33 629-632. (doi:10.3275/6884)

Steppan CM, Bailey ST, Bhat S, Brown EJ, Banerjee RR, Wright CM, Patel HR, Ahima RS \& Lazar MA 2001 The hormone resistin links obesity to diabetes. Nature 409 307-312. (doi:10.1038/35053000)

Steppan CM, Wang J, Whiteman EL, Birnbaum MJ \& Lazar MA 2005 Activation of SOCS-3 by resistin. Molecular and Cellular Biology 25 1569-1575. (doi:10.1128/MCB.25.4.1569-1575.2005)

Sun L, Hu W, Liu Q, Hao Q, Sun B, Zhang Q, Mao S, Qiao J \& Yan X 2012 Metabonomics reveals plasma metabolic changes and inflammatory marker in polycystic ovary syndrome patients. Journal of Proteome Research 11 2937-2946. (doi:10.1021/pr3000317)

Suzuki YA, Shin K \& Lonnerdal B 2001 Molecular cloning and functional expression of a human intestinal lactoferrin receptor. Biochemistry $\mathbf{4 0}$ 15771-15779. (doi:10.1021/bi0155899)

Svendsen PF, Christiansen M, Hedley PL, Nilas L, Pedersen SB \& Madsbad S 2012 Adipose expression of adipocytokines in women with polycystic ovary syndrome. Fertility and Sterility 98 235-241. (doi:10.1016/j. fertnstert.2012.03.056)

Tan BK, Chen J, Digby JE, Keay SD, Kennedy CR \& Randeva HS $2006 a$ Increased visfatin messenger ribonucleic acid and protein levels in adipose tissue and adipocytes in women with polycystic ovary syndrome: parallel increase in plasma visfatin. Journal of Clinical Endocrinology and Metabolism 91 5022-5028. (doi:10.1210/jc.20060936)

Tan BK, Chen J, Digby JE, Keay SD, Kennedy CR \& Randeva HS $2006 b$ Upregulation of adiponectin receptor 1 and 2 mRNA and protein in adipose tissue and adipocytes in insulin-resistant women with polycystic ovary syndrome. Diabetologia 49 2723-2728. (doi:10.1007/ s00125-006-0419-9)

Tan BK, Chen J, Lehnert H, Kennedy R \& Randeva HS 2007 Raised serum, adipocyte, and adipose tissue retinol-binding protein 4 in overweight women with polycystic ovary syndrome: effects of gonadal and adrenal steroids. Journal of Clinical Endocrinology and Metabolism 92 2764-2772. (doi:10.1210/jc.2007-0091)

Tan BK, Adya R, Farhatullah S, Lewandowski KC, O'Hare P, Lehnert H \& Randeva HS 2008a Omentin-1, a novel adipokine, is decreased in overweight insulin-resistant women with polycystic ovary syndrome: ex vivo and in vivo regulation of omentin-1 by insulin and glucose. Diabetes 57 801-808. (doi:10.2337/db07-0990)

Tan BK, Pua S, Syed F, Lewandowski KC, O'Hare JP \& Randeva HS $2008 b$ Decreased plasma omentin-1 levels in type 1 diabetes mellitus. Diabetic Medicine 25 1254-1255. (doi:10.1111/j.1464-5491.2008.02568.x)

Tan BK, Chen J, Farhatullah S, Adya R, Kaur J, Heutling D, Lewandowski KC, O'Hare JP, Lehnert H \& Randeva HS 2009 Insulin and metformin regulate circulating and adipose tissue chemerin. Diabetes $\mathbf{5 8}$ 1971-1977. (doi:10.2337/db08-1528) 
Tan BK, Adya R, Farhatullah S, Chen J, Lehnert H \& Randeva HS $2010 a$ Metformin treatment may increase omentin-1 levels in women with polycystic ovary syndrome. Diabetes 59 3023-3031. (doi:10.2337/db100124)

Tan BK, Adya R \& Randeva HS 2010b Omentin: a novel link between inflammation, diabesity, and cardiovascular disease. Trends in Cardiovascular Medicine 20 143-148. (doi:10.1016/j.tcm.2010.12.002)

Tartaglia LA, Dembski M, Weng X, Deng N, Culpepper J, Devos R, Richards GJ, Campfield LA, Clark FT, Deeds J et al. 1995 Identification and expression cloning of a leptin receptor, OB-R. Cell 83 1263-1271. (doi:10.1016/0092-8674(95)90151-5)

Tilg H \& Moschen AR 2006 Adipocytokines: mediators linking adipose tissue, inflammation and immunity. Nature Reviews. Immunology 6 772-783. (doi:10.1038/nri1937)

Toulis KA, Goulis DG, Farmakiotis D, Georgopoulos NA, Katsikis I, Tarlatzis BC, Papadimas I \& Panidis D 2009 Adiponectin levels in women with polycystic ovary syndrome: a systematic review and a meta-analysis. Human Reproduction Update 15 297-307. (doi:10.1093/ humupd/dmp006)

Triebel S, Blaser J, Reinke H \& Tschesche H 1992 A 25 kDa $\alpha 2$-microglobulin-related protein is a component of the $125 \mathrm{kDa}$ form of human gelatinase. FEBS Letters 314 386-388. (doi:10.1016/00145793(92)81511-J)

Trolle B, Lauszus FF, Frystyk J \& Flyvbjerg A 2010 Adiponectin levels in women with polycystic ovary syndrome: impact of metformin treatment in a randomized controlled study. Fertility and Sterility 94 2234-2238. (doi:10.1016/j.fertnstert.2010.01.057)

Tsuji S, Uehori J, Matsumoto M, Suzuki Y, Matsuhisa A, Toyoshima K \& Seya T 2001 Human intelectin is a novel soluble lectin that recognizes galactofuranose in carbohydrate chains of bacterial cell wall. Journal of Biological Chemistry 276 23456-23463. (doi:10.1074/jbc.M103162200)

Urbanek M, Du Y, Silander K, Collins FS, Steppan CM, Strauss JF III, Dunaif A, Spielman RS \& Legro RS 2003 Variation in resistin gene promoter not associated with polycystic ovary syndrome. Diabetes $\mathbf{5 2}$ 214-217. (doi:10.2337/diabetes.52.1.214)

Valkenburg O, Uitterlinden AG, Piersma D, Hofman A, Themmen AP, de Jong FH, Fauser BC \& Laven JS 2009 Genetic polymorphisms of GnRH and gonadotrophic hormone receptors affect the phenotype of polycystic ovary syndrome. Human Reproduction 24 2014-2022. (doi:10.1093/humrep/dep113)

Vicennati V, Gambineri A, Calzoni F, Casimirri F, Macor C, Vettor R \& Pasquali R 1998 Serum leptin in obese women with polycystic ovary syndrome is correlated with body weight and fat distribution but not with androgen and insulin levels. Metabolism 47 988-992. (doi:10.1016/S0026-0495(98)90356-0)

Vionnet N, Hani EH, Dupont S, Gallina S, Francke S, Dotte S, De Matos F, Durand E, Lepretre F, Lecoeur C et al. 2000 Genomewide search for type 2 diabetes-susceptibility genes in French whites: evidence for a novel susceptibility locus for early-onset diabetes on chromosome 3q27-qter and independent replication of a type 2-diabetes locus on chromosome 1q21-q24. American Journal of Human Genetics 67 1470-1480. (doi:10.1086/316887)

Volek JS, Phinney SD, Forsythe CE, Quann EE, Wood RJ, Puglisi MJ, Kraemer WJ, Bibus DM, Fernandez ML \& Feinman RD 2009 Carbohydrate restriction has a more favorable impact on the metabolic syndrome than a low fat diet. Lipids 44 297-309. (doi:10.1007/s11745008-3274-2)

Wang Q, Guo T, Tao Y, Song Y \& Huang W 2011 Association between serum adipocyte factor level and insulin resistance in polycystic ovarian syndrome. Gynecological Endocrinology 27 931-934. (doi:10.3109/09513590.2011.569597)

Wang L, Li S, Zhao A, Tao T, Mao X, Zhang P \& Liu W 2012a The expression of sex steroid synthesis and inactivation enzymes in subcutaneous adipose tissue of PCOS patients. Journal of Steroid Biochemistry and Molecular Biology 132 120-126. (doi:10.1016/j.jsbmb.2012.02.003)
Wang Q, Kim JY, Xue K, Liu JY, Leader A \& Tsang BK 2012b Chemerin, a novel regulator of follicular steroidogenesis and its potential involvement in polycystic ovarian syndrome. Endocrinology 153 5600-5611. (doi:10.1210/en.2012-1424)

Welt CK, Chan JL, Bullen J, Murphy R, Smith P, DePaoli AM, Karalis A \& Mantzoros CS 2004 Recombinant human leptin in women with hypothalamic amenorrhea. New England Journal of Medicine $\mathbf{3 5 1}$ 987-997. (doi:10.1056/NEJMoa040388)

Wen JP, Lv WS, Yang J, Nie AF, Cheng XB, Yang Y, Ge Y, Li XY \& Ning G 2008 Globular adiponectin inhibits GnRH secretion from GT1-7 hypothalamic GnRH neurons by induction of hyperpolarization of membrane potential. Biochemical and Biophysical Research Communications 371 756-761. (doi:10.1016/j.bbrc.2008.04.146)

Wickenheisser JK, Nelson-DeGrave VL, Hendricks KL, Legro RS, Strauss JF III \& McAllister JM 2005 Retinoids and retinol differentially regulate steroid biosynthesis in ovarian theca cells isolated from normal cycling women and women with polycystic ovary syndrome. Journal of Clinical Endocrinology and Metabolism 90 4858-4865. (doi:10.1210/jc.2005-0330)

Wiltshire S, Hattersley AT, Hitman GA, Walker M, Levy JC, Sampson M, O'Rahilly S, Frayling TM, Bell JI, Lathrop GM et al. 2001 A genomewide scan for loci predisposing to type 2 diabetes in a U.K. population (the Diabetes UK Warren 2 Repository): analysis of 573 pedigrees provides independent replication of a susceptibility locus on chromosome 1q. American Journal of Human Genetics 69 553-569. (doi:10.1086/323249)

Wittamer V, Franssen JD, Vulcano M, Mirjolet JF, Le Poul E, Migeotte I, Brezillon S, Tyldesley R, Blanpain C, Detheux M et al. 2003 Specific recruitment of antigen-presenting cells by chemerin, a novel processed ligand from human inflammatory fluids. Journal of Experimental Medicine 198 977-985. (doi:10.1084/jem.20030382)

Wojciechowski P, Lipowska A, Rys P, Ewens KG, Franks S, Tan S, Lerchbaum E, Vcelak J, Attaoua R, Straczkowski M et al. 2012 Impact of FTO genotypes on BMI and weight in polycystic ovary syndrome: a systematic review and meta-analysis. Diabetologia 55 2636-2645. (doi:10.1007/s00125-012-2638-6)

Wood JR, Ho CK, Nelson-Degrave VL, McAllister JM \& Strauss JF III 2004 The molecular signature of polycystic ovary syndrome (PCOS) theca cells defined by gene expression profiling. Journal of Reproductive Immunology 63 51-60. (doi:10.1016/j.jri.2004.01.010)

Wu MH, Chuang PC, Chen HM, Lin CC \& Tsai SJ 2002 Increased leptin expression in endometriosis cells is associated with endometrial stromal cell proliferation and leptin gene up-regulation. Molecular Human Reproduction 8 456-464. (doi:10.1093/molehr/8.5.456)

Xita N, Georgiou I, Tsatsoulis A, Kourtis A, Kukuvitis A \& Panidis D 2004 A polymorphism in the resistin gene promoter is associated with body mass index in women with polycystic ovary syndrome. Fertility and Sterility 82 1466-1467. (doi:10.1016/j.fertnstert.2004.04.050)

Xu A, Chan K, Hoo R, Wang Y, Tan K \& Zhang J 2005 Testosterone selectively reduces the high molecular weight form of adiponectin by inhibiting its secretion from adipocytes. Journal of Biological Chemistry 280 18073-18080. (doi:10.1074/jbc.M414231200)

Yamawaki H, Kuramoto J, Kameshima S, Usui T, Okada M \& Hara Y 2011 Omentin, a novel adipocytokine inhibits TNF-induced vascular inflammation in human endothelial cells. Biochemical and Biophysical Research Communications 408 339-343. (doi:10.1016/j.bbrc.2011. 04.039)

Yamawaki H, Kameshima S, Usui T, Okada M \& Hara Y 2012 A novel adipocytokine, chemerin exerts anti-inflammatory roles in human vascular endothelial cells. Biochemical and Biophysical Research Communications 423 152-157. (doi:10.1016/j.bbrc.2012.05.103)

Yang Q, Graham TE, Mody N, Preitner F, Peroni OD, Zabolotny JM, Kotani K, Quadro L \& Kahn BB 2005 Serum retinol binding protein 4 contributes to insulin resistance in obesity and type 2 diabetes. Nature 436 356-362. (doi:10.1038/nature03711) http://jme.endocrinology-journals.org

DOI: 10.1530/JME-12-0247 (c) 2013 Society for Endocrinology Printed in Great Britain 
Yang RZ, Lee MJ, Hu H, Pray J, Wu HB, Hansen BC, Shuldiner AR, Fried SK, McLenithan JC \& Gong DW 2006 Identification of omentin as a novel depot-specific adipokine in human adipose tissue: possible role in modulating insulin action. American Journal of Physiology. Endocrinology and Metabolism 290 E1253-E1261. (doi:10.1152/ajpendo. 00572.2004)

Yildizhan R, Ilhan GA, Yildizhan B, Kolusari A, Adali E \& Bugdayci G 2011 Serum retinol-binding protein 4 , leptin, and plasma asymmetric dimethylarginine levels in obese and nonobese young women with polycystic ovary syndrome. Fertility and Sterility 96 246-250. (doi:10.1016/j.fertnstert.2011.04.073)

Zabel BA, Nakae S, Zuniga L, Kim JY, Ohyama T, Alt C, Pan J, Suto H, Soler D, Allen SJ et al. 2008 Mast cell-expressed orphan receptor CCRL2 binds chemerin and is required for optimal induction of IgE-mediated passive cutaneous anaphylaxis. Journal of Experimental Medicine 205 2207-2220. (doi:10.1084/jem.20080300)

Zachow RJ, Weitsman SR \& Magoffin DA 1999 Leptin impairs the synergistic stimulation by transforming growth factor- $\beta$ of follicle-stimulating hormone-dependent aromatase activity and messenger ribonucleic acid expression in rat ovarian granulosa cells. Biology of Reproduction 61 1104-1109. (doi:10.1095/biolreprod61.4.1104)

Zhang Y, Proenca R, Maffei M, Barone M, Leopold L \& Friedman JM 1994 Positional cloning of the mouse obese gene and its human homologue. Nature 372 425-432. (doi:10.1038/372425a0)

Zhang J, Wu Y, Zhang Y, Leroith D, Bernlohr DA \& Chen X 2008 The role of lipocalin 2 in the regulation of inflammation in adipocytes and macrophages. Molecular Endocrinology 22 1416-1426. (doi:10.1210/ me.2007-0420)

Zhang J, Zhou L, Tang L \& Xu L 2011 The plasma level and gene expression of resistin in polycystic ovary syndrome. Gynecological Endocrinology $\mathbf{2 7}$ 982-987. (doi:10.3109/09513590.2011.569794)

Zhao Y, Fu L, Li R, Wang LN, Yang Y, Liu NN, Zhang CM, Wang Y, Liu P, $\mathrm{Tu} \mathrm{BB}$ et al. 2012 Metabolic profiles characterizing different phenotypes of polycystic ovary syndrome: plasma metabolomics analysis. $B M C$ Medicine 10 153. (doi:10.1186/1741-7015-10-153)

Received in final form 15 January 2013

Accepted 18 January 2013

Accepted Preprint published online 18 January 2013
(C) 2013 Society for Endocrinology Printed in Great Britain
Published by Bioscientifica Ltd. 